\title{
"Oh, I have slipped the surly bonds of earth":" Multinational Space Stations and Choice of Law
}

\author{
Helen Shin $\dagger$
}

The idea of space stations orbiting the Earth and inhabited by people from diverse countries is not as farfetched as it first seems. Many countries have already signed agreements governing various aspects of space station operation. But no agreement or treaty has yet addressed the issue of choice of law in space-although confiicts questions are sure to arise in the multinational context of space stations. This Comment addresses that "void," focusing on the proper choice of law regime for torts occurring between individuals on a space station. The author examines several possible regimes, finally selecting one based on a multinational agreement incorporating an arbitration clause.

Imagine this:

An American writer is traveling through Canada. While she is driving through Nova Scotia, a visiting French driver accidentally hits her car, and the writer is injured. Which state's choice of law rules-and institutions-determine which state's substantive laws will apply to the issues of the Frenchinan's liability and the American's ability to recover dainages? ${ }^{2}$

Let us change the scenario slightly:

An American oceanographer is working aboard a research vessel (which flies the Canadian fiag) as part of a scientific team investigating deep sea vents in international waters. A French geologist working on samplegatherimg equipment carelessly tosses some cables onto the ship's deck. The oceanographer trips on the cables and is injured. Which state's

1. Magee, High Flight, in Favorite Poems Old and New 203 (H. Ferris ed. 1957).

$\dagger$ A.B. 1987, Radcliffe College, Harvard University; J.D. 1990, Boalt Hall School of Law, University of California, Berkeley. The author would like to thank Professor David Caron and her classmates in the Advanced International Law Research class for their helpful criticisin.

2. Of course, these two issues-liability and damages-could be dealt with separately by a court in determining which nation's laws should apply. This technique, dépeçage, allows the forun court to apply the laws of different states to issues in one case. The technique has been applied by many courts in the United States. See, e.g., Ewing v. St. Louis-Clayton Orthopedic Group, Inc., 790 F.2d 682, 686-87 (8th Cir. 1986) (applying Illinois Workers' Compensation Act to immunity issue and Missouri law to negligence issue); Foster v. United States, 768 F.2d 1278, 1281 (11th Cir. 1985) (applying New York law to quantun meruit claims and California law to hicensing issue); Hutner v. Greene, 734 F.2d 896, 901 (2d Cir. 1984) (stating that "different substantive issues ... nay have to be resolved under the laws of different states where the choice influencing decisions differ"). 
choice of law rules-and institutions-determine which state's substantive laws will apply to the issues of the geologist's liability and the American's ability to recover damages?

We can change the scenario still further:

An American biologist is conducting an experiment aboard an orbiting inultinational space station built by the United States, Canada, Japan, and the European Space Agency. The biologist is passing through the Canadian inodule, where a French astrophysicist is repairing an instrument panel. The astrophysicist carelessly pushes aside a wrench, which floats away and imjures the biologist. Which state's choice of law rulesand institutions-determine which state's substantive laws will apply to the issues of the astrophysicist's hability and the American's ability to recover damages?

\section{INTRODUCTION}

The questions posed in each of the preceding scenarios involve the conflict of laws. At issue is what rules to apply to determine which state's substantive tort law will govern a situation involving citizens of several states. ${ }^{3}$ Of course, if the choice of law rules ${ }^{4}$ of all the states involved pointed to the same state's substantive law to determine the alleged tortfeasor's hability, one state's choice of law rules would not be crucial to the case's outcome. Unfortunately, this is not usually the case; state choice of law regimes rarely match. This problein is coinpounded by the fact that, in inost conflict of laws situations, there is often no agreement on which state's choice of law rules should determine the applicable substantive laws, let alone which substantive laws would produce the most just result.

In the first situation, the choice of law rules of the jurisdiction in which the victim brought suit would determine the governing substantive law. However, because different states may have different choice of law rules, ${ }^{5}$ it is often difficult to predict which state's laws will in fact be applied as the controlling substantive law.

The solution to the second situation is inore straightforward largely because maritine law, which governs the situation, is an overarching body of law quite separate from the laws of individual states. ${ }^{6}$ Maritime law is jus gentium and thus should be the same in every state. ${ }^{7}$ It can

3. In international law, countries are referred to as "states" and their laws as "municipal."

4. Of course, this assumes that one of these sets of choice of law rules appropriately governs the case. However, it is also possible that a separate comprehensive set of laws, much like maritime law, should govern situations such as these involving nationals of different states.

5. The various choice of law approaches are discussed in more detail at infra Sections III(A) through III(E).

6. Maritime choice of law rules are discussed at infra Section III(E).

7. Jus gentium refers to the natural law observed by all nations. BLACK's LAw DictionARY 859 (6th ed. 1990). 
either dictate the result of a suit through substantive rules or estabish which state's laws are appropriate through choice of law rules. Thus, in whatever jurisdiction the plaintiff brings suit, the choice of law rules applied under maritime law should be much the same.

But what of the third situation? A generation ago, pernanently inhabited space stations orbiting the Earth were only topics of science fiction. Today, plans for a space station are so advanced that government officials from the United States, Japan, Canada, and the inember states of the European Space Agency (ESA) ${ }^{8}$ have signed an intergoverninental agreeinent governing many aspects of space station operation. ${ }^{9}$ Along with this surge of official interest has coine concern about some of the legal implications of space station use. ${ }^{10}$

The aforementioned agreement, however, does not contain any choice of law provisions; nor do various other inultilateral treaties regnlating the signatories' activities in outer space apply to the third scenario above. ${ }^{11}$ Thus, unlike the second situation, there is no uniform choice of law regime that governs incidents aboard a multinational space station (MSS). And unlike the first situation, we are faced with an opportumity to establish such a uniform regime without upsetting or displacing existing national laws.

This Comment focuses on the selection of an appropriate choice of law regime to govern disputes between individuals ${ }^{12}$ arising out of torts occurring aboard 1nultinational space stations orbiting the Earth. ${ }^{13}$

8. The nations comprising the ESA are Austria, Belgium, Denmark, France, Germany, Italy, Ireland, the Netherlands, Norway, Spain, Sweden, Switzerland, and the United Kingdom. $H$. Mickittz \& N. Reich, Legal Aspects of European Space Activities: eSA Convention, EEC INTERnal MaRket and Common Commercial Policy 25 n.1 (1989).

9. Agreement on Cooperation in the Detailed Design, Development, Operation, and Utilization of the Permanently Manned Civil Space Station, Sept. 29, 1988 [hereinafter Space Station Agreement] (copy on file with author).

10. See, e.g., U.S. Congress Office of Tech. Assessment, Space Stations and The LAW: SELECTED Legal IsSUes-BACKGROUND PAPER, OTA-BP-ISC-41, at iii (1986) [hereinafter SPACE STATIONS] (discussing legal consequences of developing and operating a multinational space station and giving particular attention to issues involving "the application of jurisdiction, tort law, intellectual property law, and crimmal law to nations and individuals living and working in space"); 5 StUdies in AlR AND SPACE LAW (K.-H. Böckstiegel ed. 1985) (writings by contributors to international colloquium on legal issues involved in space station development and use); DeSaussure, The Impact of Manned Space Stations on the Law of Outer Space, 21 SAN DiEgo L. REv. 985 (1984); Comment, Responding to the Space Station Agreement: The Extension of U.S. Law into Space, 77 Geo. L.J. 1933 (1989) (authored by Mary McCord) (discussing treaties relating to space station use and unresolved problems relating to civil and criminal jurisdiction, choice of law, intellectual property, and tort law).

11. The provisions of these treaties and why they do not apply are discussed at infra Section II(C).

12. This Comment does not address the issue of disputes betwecn states that may arise concerning space stations. Nor does this Conment consider disputes between individuals and states.

13. The question of what substantive law should be applied to aceidents that occur outside an MSS is beyond the scope of this Comment. However, as noted at infra text accompanying notes 73- 
Although the basic rules for the use and exploration of space have been established through treaties and international conventions, this legal foundation does not specifically address tortious incidents between space station personnel. In the absence of specific rules, a modification of maritime choice of law for shipboard torts should form the basis for deciding which state's laws govern when the personnel of a MSS are accused of tortious conduct on the station. Such a regime is best implemented by an arbitration tribunal, and not by courts.

More specifically, disputes between individuals arising out of onboard torts must be resolved according to some state's internal substantive tort laws, since the space station will presuinably have no such laws of its own. In determining which state's substantive laws should be apphed, the decisionmaker should adopt a choice of law approach under which it considers three factors: the registry state of the MSS nodule in which the incident took place; the nationality of the plaintiff; and the nationality of the defendant. ${ }^{14}$

Application of this choice of law approach by municipal courts, however, might be counterproductive. Such courts may consciously or unconsciously favor the laws of their own state or be unable to exercise jurisdiction over one or more of the parties. And because the jurisdiction of the International Court of Justice extends ouly to disputes between states, ${ }^{15}$ and no other international court is empowered to adjudicate claims between individuals, adjudication by an international court is not feasible.

The choice of law determination thus should be made through arbitration undertaken according to the Model Law on International Cominercial Arbitration promulgated by the United Nations Coininission on International Trade Law (UNCITRAL). ${ }^{16}$ The Model Law sets forth sophisticated procedural guidehines for arbitration, which may be invoked (and modified) in any arbitration agreement.

The arbitration panel formed in an agreement under these guidelines would not only determine but also apply the appropriate substantive law to the dispute. Because the parties to the dispute would choose the inembers of the panel, undue partiality for any one state's laws would be

74, the Convention on International Liability for Damage Caused by Space Objects, March 29, 1973, 24 U.S.T. 2389, T.I.A.S. No. 7762, 961 U.N.T.S. 187 [hereinafter Liability Convention], may apply to some of those occurrences.

14. This Comment does not address situations where multiple plaintiffs or multiple defendants are involved.

15. Statute of the International Court of Justice, art. 34, $\$ 1$, appended to U.N. Charter, reprinted in 1985 U.N.Y.B. 1379 (1945).

16. United Nations Commission on International Trade Law, Model Law on International Commercial Arbitration, 40 U.N. GAOR Supp. (No. 17), Annex I at 81, U.N. Doc. A/40/17 (1985) [hereinafter UNCITRAL Model Law], reprinted in 24 I.L.M. 1302 (1985). 
avoided. Moreover, the states parties to the arbitration and their nationals would be deemed through their choice of law agreement to have consented to the jurisdiction of the arbitration tribunal.

I

\section{Regions Where States MAy Not AsSert Sovereignty}

Outer space is considered part of the common heritage of humankind. ${ }^{17}$ One consequence of this classification is that no state may assert sovereignty over any part of outer space. ${ }^{18}$ This lack of dominion means that no one state's municipal laws govern imcidents that occur in outer space. This Part examines how similar circumstances on Earth are handled and the drawbacks of those approaches.

\section{A. Antarctica}

Almost every bit of land on this planet is claimed by at least one state and occasionally by two or more. If conflicting claims arise, they are settled in various ways ${ }^{19}$ so that only one state exercises sovereignty over any given territory. Antarctica, however, is an exception. Several states claim various sections of Antarctica, ${ }^{20}$ and these claims are disputed to some extent by other states. These claims, though they remain unsettled, have been frozen by the Antarctic Treaty. ${ }^{21}$

The absence of territorial sovereignty by any one state, however, does not mean that Antarctica is a lawless continent with which or on which any state may do as it pleases. The Antarctic Treaty binds its

17. See Treaty on Principles Governing the Activities of States in the Exploration and Use of Outer Space, Including the Moon and Other Celestial Bodies, Jan. 27, 1967, art. I, 18 U.S.T. 2410, 2412-13, 610 U.N.T.S. 205, 207-08 [hereinafter Outer Space Treaty].

18. See, e.g., id. art. II, 18 U.S.T. at 2413,610 U.N.T.S. at 208 (outer space "is not subject to national appropriation by claim of sovereignty"). Airspace, however, is subject to claims of sovereignty. M. JANIS, AN INTRODuction to INTERNATIONAL LAw 126 (1988). This Comment will not address the issue of delimitation, that is, the deternination of where airspace gives way to outer space.

19. War is one way to settle differences over sovereignty. For example, in 1982 Argentina and the United Kingdom fought a war over which state had sovereignty over an area known as Las Islas Malvinas or the Falkland Islands.

20. These states are Argentina, Australia, Chile, France, New Zealand, Norway, and the United Kingdom. J. Myhre, The Antarctic Treaty System: Politics, Law, AND DiplomaCY 7 (1986).

21. Article IV, section 1 of the Antarctic Treaty provides that nothing in the treaty shall be interpreted as a renunciation by any signatory of previously asserted claims to territorial sovereignty in Antarctica, or as affecting a signatory's recognition or non-recognition of any other state's claim to such sovereignty. Antarctic Treaty, Dec. 1, 1959, 12 U.S.T. 794, 796, 402 U.N.T.S. 71, 74. 
signatories ${ }^{22}$ to certain standards of conduct and inethods of dispute resolution for activities concerning "the area south of $60^{\circ}$ South Latitude." ${ }^{23}$ Moreover, it is generally agreed that the rules of public international law that control states' conduct elsewhere in the world are similarly applicable in Antarctica. ${ }^{24}$ Thus, laws do regulate the conduct of states in Antarctica.

Not all issues arising froin activities in the Antarctic, lowever, concern the interests of states. This Comment focuses on disputes between individuals: What law regulates the activities of individuals in Antarctica? Generally, if a state has jurisdiction over an individual, it can apply its laws to that person. ${ }^{25}$ But the Antarctic Treaty only sets forth provisions for jurisdiction by a signatory over scientific personnel, ineinbers of their staff, and observers who are nationals of that state; ${ }^{26}$ tourists, or scientists who are nationals of non-signatory states, for exainple, are not covered. ${ }^{27}$ This lack of a coinpreliensive jurisdictional

22. The Antarctic Treaty's signatories are Argentina, Australia, Belgium, Brazil, Chile, East Germany, France, India, Italy, Japan, New Zealand, Norway, the People's Republic of China, Poland, South Africa, Spain, Sweden, the U.S.S.R., the Umited Kingdom, the United States, Uruguay, and West Germany. TreatY AfFairs Staff, OfFicz of THE LeOAl Adviser, U.S. Dep't of State, Pub. No. 9433, Treaties in Force 273-74 (Jan. 1, 1989) [hereinafter Treaties IN FORCE]. Fourteen other states have acceded to the treaty but do not fully participate in the Consultative Meetings mandated by article IX of the treaty. Id.

23. Antarctic Treaty, supra note 21 , art. VI, 12 U.S.T. at 797, 402 U.N.T.S. at 76. Whether the treaty also binds non-signatories is a hotly disputed matter. Normally, in international law a state is not obliged to follow the terms of a treaty or other agreement that it has not ratified. However, certain international legal scholars argue that certain treaties or international agreements create legal regimes that establish rights or obligations for non-signatories-legal regines that are intended to be binding erga omnes. Cf. Simma, The Antarctic Treaty as a Treaty Providing for an “Objective Regime," 19 CoRNELl INT'L L.J. 189, 189 (1986) (concluding that the Antarctica Treaty is not binding erga omnes). But see Charney, The Antarctic System and Customary International Law, in INTERNATIONAL. LAW FOR ANTARCTICA 55, 57-62 (F. Francioni \& T. Scovazzi eds. 1987) (concluding that, with certain exceptions, general international law and specific international agreements govern state actions in Antarctica).

24. Taubenfeld, The Antarctic and Outer Space: An Analogy in Retrospect, in The ANTARCTIC LEGAL REgIME 269, 275 (C. Joyner \& S. Chopra eds. 1988). For example, the Antarctic Treaty specifically states that it does not affect international law respecting the high seas within the treaty's effective area. Antarctic Treaty, supra note 21, art. VI, 12 U.S.T. at 797, 402 U.N.T.S. at 76. Some pertinent aspects of the law of the high seas are set forth at infra text accompanying notes 32-35.

25. The application of those laws, however, is not autounatic. As one commentator notes, the Antarctic Treaty "presumes that the contracting nation has jurisdiction over certain of its nationals, but the mere presumption of jurisdiction does not automatically give that nation jurisdiction to apply its laws unless that nation has so legislated that its laws specifically apply extraterritorially." Meyers, Operational Considerations: New Legal Issues, in ScIENCE, TechNology, AND Sovereignty in the Polar Regions 25, 26 (G. Schatz ed. 1974).

26. Antarctic Treaty, supra note 21 , art. VIII, $\$ 1,12$ U.S.T. at 797-98, 402 U.N.T.S. at 78.

27. Other sources of international law contain provisions for jurisdiction. For example, at least one commentator argues that "[b]y silence and the implications of Article IV, the treaty continues the [International Geophysical Year] rule that states retain jurisdiction over their stations, their nationals working at or out of the stations, and the scientific expeditions organized from their bases or their home territory." M. Peterson, Managing the Frozen South: The Creation and Evolution OF THE ANTARCTIC TREATY SYSTEM 43 (1988). Furthermore, a state also continues to 
regime may cause inconsistent results. ${ }^{28}$ For the most part, then, the laws applicable to activities in Antarctica are derived from the Treaty and, where that is silent, from various state municipal laws.

\section{B. The High Seas}

Unlike land, ouly a relatively small portion of the oceans of this planet is or can be claimed by states. ${ }^{29}$ The renuainder constitutes the "high seas," over whicl no state may claim sovereignty. ${ }^{30}$ Althougl no one state's municipal laws constitute the exclusive legal regime for the high seas, as witl Antarctica, custoniary international law and various treaties $^{31}$ provide a legal structure for the world's oceans.

On the high seas, in contrast to the Antarctic legal regine, generally applicable standards govern the exercise of jurisdiction over individuals, and international agreenients regulate the relations between states. For example, the state under whose flag a ship sails, the flag state, has exclusive (though not absolute) jurisdiction over that ship on the high seas. ${ }^{32}$ And although a state usually contmues to have jurisdiction over its own nationals even within areas under the control of another state, ${ }^{33}$ it is generally accepted that the flag state has primary jurisdiction over a defendant for incidents that occur on the high seas. ${ }^{34}$ Thus, although no single

have jurisdiction over its own nationals under international law, see infra note 33 and accompanying text, and may exercise jurisdiction over non-nationals to the extent its municipal laws permit, see, e.g., M. JAN1S, supra note 18, at 242-44 (discussing territorial principle of jurisdiction).

28. For example, in Beattie v. Umited States, 592 F. Supp. 780 (D.D.C.), aff'd, 756 F.2d 91 (D.C. Cir. 1984), the plaintiffs were the administrators of the estates of 273 passengers on board an Air New Zealand flight that crashed in Antarctica. They brought suit in the United States against the air controllers, who were U.S. Navy personnel. Id. at 781. Although the control station at McMurdo was an American facility, New Zealand claimed the territory in which the air traffic control facilities were located and in which the accident occurred. The court demed the possibility that concurrent jurisdiction could exist and reasoned that jurisdiction was available only in the United States, ignoring the effect that different legal approaches to the status of Antarctica have on determining jurisdiction. Vicuña, Air Traffic in Antarctica-The Need for a Legal Regime, in ANTARCtic Challenge III 397, 420-22 (R. Wolfrnm ed. 1988). Moreover, both the New Zealand Ministry of Transport and a Royal Commission investigated the accident and found Air New Zealand at fault. F. AUBURn, ANTARCTIC LAW AND Politics 282 (1982).

29. A coastal state can claim extensive (though not exclusive) jurisdictional rights in a zone up to 200 miles from an established baseline. R. Churchill \& A. LOWE, The LAw OF THE SEA 26, 133 (rev. ed. 1988).

30. Id. at $164-65$.

31. These treaties include the Umited Nations Convention on the Law of the Sea, U.N. Doc. A/Conf. 62/122 (1982), reprinted in U.N., THE LAW OF THE SEA: OfFICIAL TEXT OF THE UNITED Nations Convention on the LAW of THE SEA WITH ANNEXes AND INDEX at 1, U.N. Doc. LOS/Z/1, U.N. Sales No. E.83.V.5 (1983) [hereinafter Law of the Sea Convention], and the Convention on the High Seas, done April 29, 1958, 13 U.S.T. 2312, 450 U.N.T.S. 82 [hereinafter High Seas Convention].

32. R. Churchill \& A. Lowe, supra note 29, at 168-69.

33. Id. at 169; see also M. SHAW, INTERNATIONAL LAW 357 (1986).

34. R. Churchill \& A. Lowe, supra note 29, at 169. 
set of municipal laws governs which substantive laws should be applied, there is a uniform rule of international law from which a choice of law rule could be drawn. ${ }^{35}$

II

THE NEED For CHOICE of LAW RULES

Although there are presently no space stations, the United States Congress has allocated substantial amounts of money for space station research and development. ${ }^{36}$ In preparation for an eventual station, the governments of the Umited States, Canada, Japan, and the ESA states have signed an intergovernmental "Space Station Agreement" and a memorandum of understanding regarding the developinent of a space station. ${ }^{37}$ While an MSS nay not be functioning in tinie to conıniemorate the five-hundredth auniversary of Christopher Columbus' landing in the New World in 1492, developing a functioning space station at sone time $\mathrm{m}$ the near future is certainly well within our grasp. The inpending development of operative space stations necessitates the formulation of choice of law rules to govern legal disputes arising on those stations.

\section{A. Reasons for Promulgating a Choice of Law Agreement}

\section{Predictability and Fairness}

The desire for just and uniform application of law drives the search for a consistent choice of law methodology. Applying one set of laws to an alleged tort if the plaintiff sues in one state, while applying another if the plaintiff happens to sue in another state or pursues her remedy through diploniatic channels may lead to wildly inconsistent outcomes. It would also be unjust to apply different sets of laws as a result of afterthe-fact responses to a particular incident, since the reactions will often depend on political considerations, as they do in terrestrial incidents. Finally, prior negotiation and planning could resolve many possible disputed issues that would otherwise require resort to adjudicative bodies.

If no constraints are established on whicli state's laws should apply to the plaintiff's suit, several unfortunate consequences often result. First, the body of law that does develop may be higlily idiosyncratic. If

35. For a discussion of the limitations of maritime law as a model for choice of law in space, see infra text accompanying notes 153-65.

36. By October 1989, the U.S. had spent approximately two billion dollars in planning a space station. Future of Space Station in Peril, UPI, Oct. 31, 1989 (LEXIS, Nexis library, UPI file). However, the budget cuts imposed by the Gramm-Rudman-Hollings Act may decrease by up to $\$ 17.6$ million the funding available for such research and planning. NASA, NASA Budget Faces \$15S Million in Cuts, Space Station Axed By \$17.6 Million, Daily Rep. for Executives (BNA), Dec. 4, 1989, DER No. 231.

37. Comment, supra note 10, at 1933-34. 
the plaintiff sues in court and the foruin simply applies its own substantive laws, similar situations may result in differing or inconsistent determinations of hability inerely because plaintiffs choose to litigate in different fora. ${ }^{38}$ Consistency in law, especially in international contexts, can ouly be desirable and will be lessened by allowing plaintiffs to "sliop" for a forum that will give them the outcome they want.

Second, even if a given forum utilizes foreign law im accordance with some choice of law theory, no one-not even the plaintiff-can predict exactly what substantive laws will eventually govern her suit. Although the plaintiff (or her lawyer) could try to predict which state's laws will be chosen (using the forum's prior conflict of laws cases and/or applicable statutes), the very novelty of space law and its international aspects could create confusion.

Finally, the law is not ouly a compensatory mechanism, but is also a deterrent. This function is compromised when the governing law is uncertain. If a potential tortfeasor knew that she would be subject to a strict hability regime, for exainple, she would probably act more cautiously than if the laws governing her conduct required the plaimtiff to show that she was negligent. ${ }^{39}$ In addition, if she knew there was some uncertainty as to the governing law, she might choose to take certain risks. Although differences in the standards of behavior in states currently engaged in planning the MSS are not that extreine, people from

38. The plaintiff can, for example, choose the forum that will allow for the largest amount of damages. She also can choose to litigate in her home state if the convenience of doing so outweighs other considerations. If the suit is for wrongful death, the victim's heirs have even more reason to hitigate in the victim's home state. They are unlikely to have had contacts with other countries that would otherwise influence the choice of forum and are more hikely to expect that the law with which the victim was most familiar will govern. The plaintiff, however, can be forced to bring suit in the defendant's home state if no other state's courts have jurisdiction over the defendant. In any of these cases, the defendant can receive either more or less favorable treatment than an impartial forum would accord her, simply because of her nationality.

39. Of course, the consequences to the defendant may be effective as a deterrent to careless behavior, regardless of the nature of liability under the regime. First, the personnel of a space station are exceedingly vulnerable to breaches of the station's physical integrity. If, for example, someone forgets to close an airlock properly or misreads a monitor, that mistake could kill everyone aboard. A crewmember is more likely to guard against any kind of negligence, whether her own or another's, because death or catastrophe could result. Second, space travel and research are still uncommon, and the extensive press coverage that surrounds manned spaceflight is likely to continue. Consequently, the threat of adverse press coverage and public attention for such mishaps may be a further restraint. Third, the common training (as well as sociahization) the crewmembers probably will undergo, combined with the close quarters they will share, may make at least intentional tortious behavior much less common aboard an MSS than in evaryday society.

On the other hand, such intentional behavior may be more likely to occur aboard an MSS. Crewmembers may be subject to even more stress while in space beeause they live in close quarters, are pressured to use every available moment to accomplish their missions, and are isolated from friends and family. In such a stressful environment, a crewmember could resort to deliberately tortious behavior. The screcning procedures to select crewmembers should continue to be rigorous as they are for astronauts and sliuttle crew members. 
different states may hold different assumptions as to, for example, the appropriate extent of liability.

These and otlier considerations become more important in the context of space projects. Some of the space sliuttles designed, built, and registered by the U.S. liave already carried crewmembers from other states. ${ }^{40}$ Given the cooperation and participation by several states in the planning of a multimational space station, it is reasonable to assume that the personnel of sucli a station will also be of diverse nationalities.

\section{Failure of Standard Contract Law}

To select choice of law rules, individual participants could stipulate the applicable law by contract. However, this approacli presents several difficulties. Contracts are usually formed between two parties. Thus, several choice of law contracts might be necessary to govern comprehensively the rights of individual parties. ${ }^{41}$ Requiring all crewmembers to sign a contract with a single controlling entity is not a viable option, since tlie MSS will probably be a cooperative effort among states, not an individual multinational entity's venture. ${ }^{42}$ As a result, there will be no true controlling entity, altliouglı under the Space Station Agreement the United States will be responsible for overall direction of the space station. ${ }^{43}$

Another solution to this problein, form contracts, could be open to the cliallenge thiat they constitute invalid contracts of adhesion. In order to achieve any consistency in clioice of law, the contracts would liave to be standardized and each crewmember would have to sign one before boarding the MSS; no one crewinember could negotiate tlie terms of the clioice of law contract. Thus, the contracts would liave to be presented as a fait accompli to the crewmembers in order to be effective.

As an alternative, allowing states to make contracts specifying the goverming substantive law might reduce the number of contracts needed if the number of participating states was less than the number of

40. The space shuttles have, for example, carried a member of the Canadian Navy, a member of the French Air Force, and a nephew of King Fahd of Saudi Arabia. Shuttle Lands Safely and Is Hailed as a Success, N.Y. Times, June 25, 1985, at C6, col. 1; Space Shuttle Crew of 7 is Poised for Start Today of 8-Day Mission, N.Y. Times, Oct. 5, 1984, at D17, col. 1.

41. For example, if five people participate in an MSS, a total of ten contracts would have to be signed in order to ensure that the choice of law relationship between any two of the crewmembers was defined. If one more person is added, the number of contracts increases to fifteen; if two are added, the total is twenty-one. The equation describing the number of contracts necessary, $\Sigma$, as a function of the number of crewmembers, $c$, is $\Sigma(c)=(x-1)$; in other words, the sum, from $x=1$ to $x=c$, of $x-1$. For example, for 4 crewmembers, one would need $(1-1)+(2-1)+(3-1)+$ $(4-1)=6$ contracts.

42. This Comment assumes that an MSS will issue from a cooperative effort among states, as its name suggests and as efforts to date have done.

43. Space Station Agreement, supra note 9, art. 7. 
crewmembers. Such contracts would also answer the adhesion contract objection, for while the contracts might be standardized, the states would presumably have the resources, as well as the influence, to negotiate the contracts' terms. But such contracts would take a substantial amount of time to arrange unless the general principles were agreed upon in advance; in addition, the contracts would have to be renegotiated for each mission. Further, if the participating states agreed that certain principles should govern the choice of substantive law, why not embody these choice of law rules in a formal treaty or convention rather than a simple, time-limited contract?

\section{B. Structure of the Proposed Agreement}

The ultimate legal goal of spacefaring states should be a comprehensive Space Code or other separate international body of substantive law. ${ }^{44}$ A separate body of space law would ensure that individuals engaged in a common effort will be treated equally regardless of nationality. Although such a code might not cover every contingency, it would at least provide a foundation on which to build and a pattern to follow in novel situations.

In the ordinary course of events, however, such a goal probably will not be attained until long after the need arises. It will be difficult to persuade states to agree on all the details of proposed provisions, and even more difficult to persuade them to ratify such a code and enforce its provisions with any haste. In the interim, without such a code, a unform choice of law methodology would minimize uncertainty as to the applicable law without indiscriminately imposing the substantive laws of one state upon the citizens of another.

Interested states should draft a convention setting forth such a choice of law methodology. Before signing, states would have to weigh the benefits and costs of complying with such an agreeinent in hight of their desire or capacity to participate in an MSS. ${ }^{45}$ Once a state signed the convention, its nationals would be bound by the provisions.

44. That is, courts should "apply a choice of law methodology to select or develop a rule of law specially suited for the resolution of space law disputes." Comment, Problems in the Resolution of Disputes Concerning Damage Caused in Outer Space, 59 Tul. L. REv. 747, 772 (1985) (authored by Marc Firestone).

45. Individuals participating in multinational space ventures who are not citizens of any signatory state would not be subject to the terms of my proposed choice of law convention. To ensure that all the station's personnel would be subject to the same legal rules, nationals of nonsignatory states could be required to accept the convention's terms as a condition to participation. Unfortunately, this solution would raise the same adhesion objections levelled against standard contracts. See supra text accompanying notes 43-44. Presuinably a state's knowledge that failing to sign would leave its citizens in this predicament would enter its calculus of whether to sign. Indeed, this may encourage more states to sign. 
In connection with these choice of law rules, the proposed convention would require that the plaintiff pursue compensation through an arbitration tribunal, ${ }^{46}$ rather than through a suit in a state or international court. The arbitration tribunal would determine the governing law according to the convention's choice of law methodology, and apply that law to the dispute between the individuals before it. ${ }^{47}$ The tribunal would otherwise operate according to the UNCITRAL Model Law. ${ }^{48}$ The UNCITRAL Model Law apparently has not yet been used in connection with the settlement of tort disputes. Nonetheless, it constitutes the most recent and most sophisticated set of arbitration rules available, ${ }^{49}$ and at least twenty-six states and eight international organizations commented on the various drafts that preceded the final draft adopted June 21, 1985..$^{\text {so }}$

There may remain some objections to enacting such a convention. First, it is by no ineans obvious that permitting an individual plaintiff to seek compensation from another individual for her injuries is the optimal solution. The proper parties inay imstead be the respective governments of those mdividuals. Many of the extant agreements governing the use of outer space are intergovernmental instruments, and envision the enforcement of rights and habilities by states, not individuals. ${ }^{51}$ But while this system was estabhished and may have operated successfully when the only participants in outer space activities were the governments of the Soviet Union and the United States, disputes are likely to be exceedingly more complex as the nuniber of parties imcreases.

46. For background on the role of arbitration in space activities, see Böckstiegel, Arbitration and Adjudication Regarding Activities in Outer Space, 6 J. SPACE L. 3 (1978).

47. See infra notes $\mathbf{1 8 3 - 9 2}$ and accompanying text.

48. UNCITRAL Model Law, supra note 16. The Model Law sets out default parameters for procedures in international commercial arbitration, subject to any contrary agreement by the parties. The only provisions of the UNCITRAL Model Law that would be inapplicable to this Comment's proposed convention would be article 1, clause 1 (restricting the scope of the Model Law's application to international commercial arbitration) and article 28, clause 2 (failing a designation by the parties of the applicable substantive law, the arbitration tribunal will determine the governing law according to the conflict of laws rules which it deems applicable).

49. Rovine, International Arbitration and Alternative Methods of Dispute Resolution, in Proceedings of the AMERican Society of INTERNATIONAL LAW 333, 333 (1985).

50. See U.N. Comm'n on Int'l Trade Law, Analytical Compilation of Comments by Governments and International Organizations on the Draft Text of a Model Law on International Commercial Arbitration: Report of the Secretary General, with Addenda, U.N. Doc. A/CN.9/263, A/CN.9/263/Add.1-3, reprinted in 1 UNCITRAL MODEL LAW OF INTERNATIONAL Commercial ARbitration: A Documentary History (1985).

51. The Outer Space Treaty, for example, provides that "States Parties to the Treaty shall bear international responsibility for national activities in outer space." Outer Space Treaty, supra note 17, art. VI, 18 U.S.T. 2410, 2415, 610 U.N.T.S. 205, 209. The Liability Convention states, inter alia, that "[a] State which suffers damage, or whose natural or juridical persons suffer damage, may present to a launching State a claim for compensation for such damage." Liability Convention, supra note 13, art. VIII, § 1, 24 U.S.T. 2389,2395 , T.I.A.S. No. 7762, at 7, 961 U.N.T.S. 187, 191. 
In addition, the increasingly private commercial use of space seems to signal a shift away from public rights to laws apphied to and enforced by private individuals. ${ }^{52}$ U.S. courts, for example, have developed a body of law based on federal statutes to govern the taxation of activities on corporate satellites. ${ }^{53}$ Although an MSS may initially be a state or quasigovernmental undertaking, it is likely that it will increasingly serve the needs of private enterprises. ${ }^{54}$ Consequently, tlie law governing activities aboard an MSS should shift from public international law to inunicipal law.

A second objection is that international arbitration inay not be the appropriate inechamin to resolve issues of liability and compensation. The plamtiff might instead file suit in permanent international courts ${ }^{55}$ or domestic courts. However, litigation in any forum tends to be more costly and timie-consuming than arbitration. And altlough the parties might be able to resolve their dispute through diploinatic channels, ${ }^{56}$ the chances for resolution through sucl an approacli are uncertain. There is no established formal procedure for coinpensation, and pohtical pressures inay hinder rather than help expedite a settlement.

Third, one could simply answer the question of which state's laws should apply to an incident involving more than one jurisdiction when the issue actually arises. After all, any proposal regarding activities in outer space rapidly becoines outdated largely because technology continues to change. This constant cliange provides a forceful incentive to delay selecting a choice of law theory until one is actually needed. ${ }^{57}$ If a

52. Cf. N. Goldman, AMERICAN Space LAw at vii (1988) ("Space law and indeed space activities can be divided into two phases. The first phase, lasting from 1957 to circa 1980, was the era of international public law. ... In the space law realm the new era can be categorized by the atrophy and obsolescence of most space treaties and the shift toward a domestic law of outer space.").

53. See, e.g., Communications Satellite Corp. v. United States, 625 F.2d 997 (Ct. Cl. 1980) (holding that certain distributions of an international satellite consortium to a federal taxpayer were not taxable under Internal Revenne Code). The activities regulated thus far by American courts have involved only Umited States nationals and have been activities sponsored by private enterprises. Although the first space station put into orbit (currently in the planning stages) will be a joint venture of the governments of several nations, commercial ventures will almost certainly continue.

54. For example, several pharmaceutical companies have shown an interest in producing drugs on outer space platforms. N. GoLDMAN, supra note 52 , at 100.

55. But see Böckstiegel, supra note 46 , at 5-6 (noting difficulty of differentiating between adjudication and arbitration).

56. The Liability Convention, for example, contemplates that inost claims for compensation will be handled through intergovernmental negotiation and diplomacy. See Liability Convention, supra note 13, arts. IX-XII, 24 U.S.T. at 2396-97, T.I.A.S. No. 7762, at 8-9, 961 U.N.T.S. at 191-92. If an agreement is not reached within a year after the aggrieved nation presents its claim to the allegedly liable country, however, then a three-meinber arbitration panel is appointed. Id. arts. XIV-XV, 24 U.S.T. at 2398, T.I.A.S. No. 7762, at 10, 961 U.N.T.S. at 192.

57. See SPACE STATIONS, supra note 10 , at 55 . Other possible objections to a choice of law selection are that setting up a system too far in advance may undnly restrict later options, and that contracts would be sufficient to resolve any legal problems. Id. at 56 . The first issue is addressed by 
choice of law approach is selected with a particular technology in mind, for example, that approach may generate an unforeseen and undesirable result when the technology changes.

Nevertheless, both anticipating and avoiding problems, as well as reacting to existing ones, are useful strategies. Setting forth choice of law guidehnes before they are needed would, for example, give notice to parties of the apphicable law. If the Canadian defendant in the introductory hypothetical had simply assumed that Canadian law still governed his actions, the apphication of French or American law might have conne as quite a slock. In addition, establishing the choice of law structure beforehand would enable MSS builders and operators to obtain insurance more readily. If an insurance company could predict with reasonable certainty which states' laws imight apply to a case, it might be less reluctant to insure such an undertaking. ${ }^{58}$

\section{Existing International Agreements}

A special choice of law convention would be unnecessary if international agreements already exist that determine the laws governing individuals' suits for extraterrestrial torts. The Hague Conference on Private International $\mathrm{Law}^{59}$ has produced several choice of law conventions which imght qualify. Two of these deal with the law to be applied in tort cases, ${ }^{60}$ but none contemplates any application to incidents in outer space. A separate convention deahing with torts occurring in outer space is therefore necessary unless existing agreements on outer space activities resolve this issue.

There are four treaties that regulate the use of outer space. These

making the proposed choice of law convention explicitly an interim measure, subject to later modification or revocation. The second concern is addressed directly at supra notes $41-43$ and accompanying text.

58. For more on the influence of insurance on activities in outer space, see Atney-Yurdin, Insuring Third-Party Liability for Commercial Outer Space Enterprises, 3 INT'L Prop. INvEST. J. 325 (1987); Magdelenat, Spacecraft Insurance, 7 ANNALS AIR \& SPACE L. 363 (1982).

59. "Private international law" is more commonly known as "conflict of laws" in the United States. Black's LaW DictionaRY 1196 (6th ed. 1990).

60. These are the Hague Convention on the Law Applicable to Products Liability, Oct. 2, 1973, 1056 U.N.T.S. 187, reprinted in 21 AM. J. CoMP. L. 150 (1973), and the Hague Convention on the Law Applicable to Automobile Accidents, May 4, 1971, cited in Y. LoussouARN \& P. BOUREL, DROIT INTERNATIONAL PRIVE \ी 404 (3d ed. 1988). 
are the Outer Space Treaty, ${ }^{61}$ the Astronaut Treaty, ${ }^{62}$ the Liability Convention, ${ }^{63}$ and the Registration Convention. ${ }^{64}$ The United States, Canada, and Japan are signatories to all four of these treaties, as are alniost all the niembers of the ESA. ${ }^{65}$

The Outer Space Treaty is the earliest and most general of these agreements. It provides that the registry state of an object launched into outer space "sliall retain jurisdiction and control over such object, and over any personnel thereof, while in outer space or on a celestial body."66 The registry state ${ }^{67}$ thus would have "jurisdiction and control" over MSS personnel of all nationalities while they remamed on the station. ${ }^{68}$ But the state would lose that power once the plaimtiff and the alleged tortfeasor returned to Earth and ceased to be "in1 outer space." Enforcenient of the registry state's laws or regulations against sonieone not a national of the registry state would at that poimt be difficult or impossible. Thus, unless a registry state allows an MSS to establish its own court system or gives an MSS commander the authority to nake legally binding judgments of liability, the Outer Space Treaty's jurisdictional provision cannot form the basis for a choice of law regime. ${ }^{69}$

The Registration Convention provides that the state tliat launches or procures the launching of a space object "shall register the space object by means of an entry in an appropriate registry which it shall maintain."70 The Convention merely refers its signatories back to the Outer Space Treaty's clause on "jurisdiction and control" to define the legal consequences of registration ${ }^{71}$ and is thus no help in formulating a choice of law regime.

The Astronaut Treaty contains no provisions that would aid a court

61. See supra note 17.

62. Agreement on the Rescue of Astronauts, the Return of Astronauts, and the Return of Objects Launched into Outer Space, April 22, 1968, 19 U.S.T. 7570, 672 U.N.T.S. 119 [hereinafter Astronaut Treaty].

63. See supra note 13.

64. Convention on Registration of Objects Launched Into Outer Space, Jan. 14, 1975, 28 U.S.T. 695, T.I.A.S. No. 8480, 1023 U.N.T.S. 15 [hereinafter Registration Convention].

65. Spain has not signed the Astronaut Treaty, TREATies IN Force, supra note 22, at 275; Ireland, Italy and Norway have not signed the Registration Convention, id. at 370-71.

66. Outer Space Treaty, supra note 17, art. VIII, 18 U.S.T. 2410, 2416, 610 U.N.T.S. 205, 209.

67. Only one state may register a space object. Registration Convention, supra note 64 , art. II, 28 U.S.T. at 698-99, T.I.A.S. No. 8480, at 4-5, 1023 U.N.T.S. at 17.

68. It is debatable whether this "jurisdiction and control" provision empowers the registry state to establish a statute or code to fix liability and damages.

69. Even if one argued that this jurisdictional provision in effect supplies the "place" or "state" in which a tort has taken place, the ability to exercise jurisdiction does not necessarily give a state the power to apply its own substantive laws. A state's choice of law rules may require a court that has jurisdiction over a claim to apply the substantive laws of another jurisdiction or state.

70. Registration Convention, supra note 64, art. II, § 1, 28 U.S.T. at 698, T.I.A.S. No. 8480, at 4, 1023 U.N.T.S. at 17.

71. Id. art. II, § 2, 28 U.S.T. at 699, T.I.A.S. No. 8480, at 5, 1023 U.N.T.S. at 17. 
in ascertaining the proper law to apply. ${ }^{72}$ It merely requires signatory states to aid astronauts in the event of accident or emergency, and to return objects launched into outer space and astronauts who have entered territory under its jurisdiction.

The Liability Convention fixes hability for damage caused by a "space object,"73 but not damage or injury caused by a person or persons on board such a space object. ${ }^{74}$ Thus, while the Liability Convention would apply if a member of an MSS were, for example, injured by a docking supply ship, it would not apply if a crewinember negligently injured another person on board that MSS.

As previously inentioned, the Umited States, the meinber states of the ESA, Japan, and Canada have signed an agreement on the operation of a proposed space station. ${ }^{75}$ That agreeinent, the Space Station Agreement, dictates that each party shall register the portions of the space station it provides. ${ }^{76}$ Pursuant to the Outer Space Treaty and the Registration Convention, the registering party will thus "retain jurisdiction and control over the eleinents it registers."77 The agreeinent also provides that each party will retain jurisdiction and control "over personnel in or on the Space Station who are its nationals."78 All this is well and good, but it still leaves us with the same problein as we faced with the

72. The Astronaut Treaty provides that a nation party to the agreement should: (1) notify the launching nation and the Secretary-General of the United Nations if it learns that the personnel of a spacecraft are in distress or that a space object (e.g., a satellite) has returned to Earth; (2) take all possible steps to rescue spacecraft personnel if the spacecraft lands in territory under its jurisdiction or in any place not under the jurisdiction of any nation; and (3) recover and return to the launching authority space objects that have returned to Earth in territory under its jurisdiction or in any place not under the jurisdiction of any nation. See Astronaut Treaty, supra note 62, arts. 1-5, 19 U.S.T. at 7573-75, 672 U.N.T.S. at 121-23.

73. Liability Convention, supra note 13 , arts. II-IV, 24 U.S.T. at 2392-93, T.I.A.S. No. 7762, at $4-5,961$ U.N.T.S. at $\mathbf{1 8 9 - 9 0 .}$

74. It might be possible to invoke the Liability Convention by arguing that the wrench in the hypothetical is the relevant "space object" that caused the damage. Article I of the Convention states that "[t]he term 'space object' includes the component parts of a space object as well as its launch vehicle and parts thereof." Liability Convention, supra note 13, art. I, 24 U.S.T. at 2392, T.I.A.S. No. 7762, at 4, 961 U.N.T.S. at 189. A wrench aboard an MSS could thus constitute a "component part" of that station. However, article III, the section of the Convention most relevant to space stations, addresses damage "caused ... to a space object of one launching state or to persons or property on board such a space object by a space object of another launching state." Id. art. III, 24 U.S.T. at 2392 , T.I.A.S. No. 7762 , at 4,961 U.N.T.S. at 190 . This provision implies that the thing causing the dainage must be an object external, not internal, to the MSS. It also ignores the fact that it is a person, not an object, that actually caused the damage.

75. See supra notes $8-9$ and accompanying text.

76. Space Station Agreement, supra note 9, art. 5, cl. 1.

77. Id. art. 5 , cl. 2.

78. Id. This may or may not represent a departure from the Outer Space Treaty's provisions. Recall that a state registering a "space object," including a module of the space station, retains jurisdiction and control "over any personnel thereof." Outer Space Treaty, supra note 17, art. VIII, 18 U.S.T. at 2416,610 U.N.T.S. at 209. Thus, if a national of one state happened to be considered "personnel" of another state's inodule, both states would be able to exercise jurisdiction over her. 
Outer Space Treaty: jurisdiction only applies to parties while they remain in outer space.

III

\section{The Shortcomings of Current Choice of LAw}

\section{APPROACHES}

Given the lack of specific choice of law guidelines applicable to outer space activities, it seems that a decisionmaker must fall back on general choice of law principles. Current approaches to choosing the governing substantive law on Earth, however, should not be extended to incidents occurring aboard an MSS. All of the current approaches have serious policy drawbacks, some of which have already been recognized and criticized in earthbound situations. Even more difficulties would probably surface if these choice of law approaches were applied to an incident that occurred in outer space. This Part discusses these approaches and their drawbacks in thc context of events on board an MSS in outer space.

\section{A. The Traditional Approach-Lex Loci Dehicti}

\section{Principles of Choice of Law Under Lex Loci Delicti}

The traditional choice of law approach for torts is to apply the law of the place where the plaintiff was injured (the lex loci delicti commissi). ${ }^{79}$ The main advantages of this approach are unformity and predictability of result. A court can readily determine the place of injury and then apply the law of that state. Because other factors are irrelevant, the plaintiff has no incentive to "sliop around" for inore favorable laws or more sympathetic courts.

Most of the states involved in designing the currently contemplated MSS, with the exception of inost of the Umited States, ${ }^{80}$ apparently follow the traditional approacl of lex loci delicti. In Canada, the courts still use this approach, although there is apparently some pressure toward change. ${ }^{81}$ Japanese courts follow the Horei, a code that dictates what

Although this may seem out of the ordinary, it certainly comports with the international law principle that a state retains jurisdiction over its own nationals wherever they go.

79. 2 E. RABEL, The CONFLICT OF LAws 235-37 (2d ed. 1960). More accurately, the lex loci delicti is the law of the place "where the last event necessary to inake an actor hable for an alleged tort takes place." RESTATEMENT OF CONFLICT OF LAws § 377 (1934) [hereinafter RESTATEMENT]. This "last event" is typically injury to the victim. This is the traditional inethod, but some American courts have begun to take into account the location of the actor's alleged negligence in determining the "place of wrong." See, e.g., Beattie v. United States, 756 F.2d 91, 104OS (D.C. Cir. 1984) (Federal Tort Claims Act focuses on the place where the negligent or wrongful act or omission occurred); Sami v. United States, 617 F.2d 755, 761-63 (D.C. Cir. 1979) (same).

80. See infra notes $91-93$ and accompanying text.

81. See, e.g., J.-G. CASTEl, CaNAdian Conflict of Laws 606-15 (2d ed. 1986) (governing 
law should be applied in a given situation. ${ }^{82}$ With respect to torts, the Horei directs the adjudicator to follow a form of the traditional approach. ${ }^{83}$

The ESA does not have an agreement or convention on conflict of laws that its member states or their nationals must observe for tort disputes. ${ }^{84}$ Although the states that constitute the ESA must submit disputes among the member states or between a member and the ESA itself to arbitration, mdividual parties are still free to sue for damages. ${ }^{85}$ The member states of the ESA differ in their approaches to choosing the governing law, but most follow the lex loci delicti in suits between individuals. ${ }^{86}$ As one commentator has noted, "[t]he 'revolution' that has raged about the American conflicts rules for torts has been noted in Europe but has had no effect there."87

\section{Drawbacks to Using the Traditional Approach}

Despite its advantages, the traditional rule as applied to outer space activities would not necessarily garner broad-based support. Although inany states generally follow the rule of lex loci delicti for torts, ${ }^{88}$ several of the states parties to the Space Station Agreement have begun to follow different choice of law approaches. Simce the rule of lex loci delicti does

law under Canadian choice of law rules is that of place of tort); id. at 49 ("In Canada the courts should not feel ashamed to use the traditional methodology of jurisdiction-selecting rules to solve conflict of laws cases.") (emphasis added). Canadian courts apply the law of the state of registry for incidents occurring aboard a ship while it is on the high seas, $i d$. at 614 , and by analogy would probably apply the law of the state of registry for incidents occurring aboard an MSS.

82. See A. Ehrenzweig, S. IKehara \& N. Jensen, American-Japanese Private InTERnational LaW 18, 41, 51 (Bilateral Studies in Private International Law No. 12, 1964).

83. See id. at 51. But see infra note 89 and accompanying text (Japanese courts may nonetheless exercise flexible approach).

84. However, the member states of the European Community, which includes all the members of the ESA, have promulgated a choice of law convention to govern only contractual obligations. The European Communities' Convention on the Law Applicable to Contractual Obligations, 23 O.J. EUR. COMM. (No. L 266) 1 (1980), signed in Rome on June 19, 1980, was undertaken largely to discourage forum shopping by minimizing the differences in the member states' choice of law rules. Lando, The EEC Convention on the Law Applicable to Contractual Obligations, 24 CoMmON MKT. L. REV. 159, 159-60 (1987).

85. European Space Agency Convention, opened for signature Dec. 31, 1975, 14 I.L.M. 864, 881-82.

86. See, e.g., M. Aguilar Navarro, Lecciones De Derecho Civil Internacional ESPAÑOL 389-90 (2d ed. 1983) (Spain follows lex loci delicti, but where the injured party and defendant are of the same nationality, domicile or residence, the law of the country in which they are nationals, domiciliaries, or residents applies); U. Drobnig, American-German Private INTERNATIONAL LAW 213-14 (2d ed. 1972) (West Germany does not follow lex loci delicti, Denmark follows lex loci delicti); H. EEK, THE SwEDISH CONFLICT OF LAws 269 (1965) (Sweden follows lex loci delicti); Y. LOUSSOUARN \& P. BOUREL, DROIT INTERNATIONAL PRIVE 270-72 (3d ed. 1988) (France follows lex loci delicti); A. Phillp, American-Danish Private InTERnational LAw 25 (Bilateral Studies in Private International Law 1957).

87. U. DROBNIG, supra note 86 , at 213 (footnote omitted).

88. E. RABEL, supra note 79 , at $235 \&$ n. 20 . 
not command the monohithic support that it once did, it should not be blindly transferred to outer space incidents.

As an example of this eroding support, consider the Japanese Horei: it nominally dictates the use of the lex loci delicti. Yet a Japanese court often will construe the Horei in order to apply the law of the plaintiff's nationality. ${ }^{89}$ Furthermore, some of the ESA member states now follow a modified version of the traditional rule; others have begun to change their choice of law rules even more drastically. ${ }^{90}$

Many courts in the United States followed the traditional rule until the second half of the twentieth century, ${ }^{91}$ but the state courts of the United States have now largely abandoned the traditional approach. ${ }^{92}$ As one counmentator has put it, "the lex loci dehcti rule has given way to a bewildering variety of flexible modern approaches . . . united primarily in disdain for the traditional choice of law system."93

Moreover, what constitutes the "place of injury" under the lex loci delicti approach is problematic. One could indulge in the legal fiction that the registration of the space station with a state makes the station an actual orbiting fragment of the registry state, so that any tort is actually committed "in" the registry state. This justification was formerly used in maritime law with respect to ships, which were referred to as "floating

89. A. Ehrenzweig, S. Ikehara \& N. JenSEN, supra note 82, at 41, 51-55. This is especially frequent in cases involving automobile accidents occurring in Japan between non-Japanese. Id. at 53.

90. Austria, for example, has passed a statute that directs the court to apply the lex loci delicti unless the parties have "a stronger connection to the law of one and the same other state," in which case the latter state's laws apply. Federal Statute of 15 June 1978 on Private Intemational Law [BGB No. 304/1978] § 48(1) (1978), reprinted in E. Palmer, The Austrian Codification of CoNflicts LAw 57, 75 (1978). Belgium also follows the lex loci delicti unless there is no significant link with the place of injury (other than the injury) and the preponderance of contacts is with some other state. In that case, the other state's laws apply. 2 F. RIGAUx, Drort INTERNATIONAI PRIVE 496 (1979) (Belgium).

In England, English law applies when the tortious conduct occurs in England. Liability is judged by English law if the conduct occurred outside England but only if the conduct is also punishable under the law of the place where the conduct took place. J. Collier, CoNFLICr of LAws 184 (1987). Ireland's choice of law rules seem to be leaning toward the "most significant relationship" technique of the Restatement. W. BINCHY, IRISH CoNFLICTS OF LAw 569, 578-79 (1988). And in Switzerland, lex loci delicti applies if it was foreseeable that an imjury would occur in the actual place of injury. There are, however, two exceptions: where the perpetrator and victim are residents of the same state, the law of that state applies; and where the act constitutes a violation of a precxisting juridical relationship, the law applicable to that relationship applies to claims arising out of the act. Bucher, Les actes illicites dans le nouveau droit international privé suisse, in 9 LE NOUVEAU DROIT INTERNATIONAL PRIVE SUISSE 116-23 (F. Dessemontet ed. 1988).

91. See RESTATEMENT, supra note 79, § 377.

92. See R. CRamton, D. Currie \& H. Kay, Conflict of Laws 226-27 (4th ed. 1987) (as of publication date, only 15 out of 50 states apply the traditional choice of law rules); see also Kay, Theory into Practice: Choice of Law in the Courts, 34 MERCER L. REV. 521 (1983) (discussing the choice of law approaches advanced by various state courts).

93. Korn, The Choice-of-Law Revolution: A Critique, 83 Colum. L. REv. 772, 776 (1983). 
islands." 94 This analogy was later rejected in maritime law, ${ }^{95}$ and the application to outer space would be a strained one. As one commentator opined, "[f]or outer space, there is no lex loci delicti commissi. Thus, this venerable rule, so generously apphed in both common and civil law countries, is impossible to follow for space related torts." 96

The traditional rule, however, has disadvantages extending beyond both its obsolescence in states currently involved in the development of the MSS and its problematic determmation of where a tort occurs in outer space for purposes of jurisdiction. For one, a strict rule of "registry state law" may lead to unjust or illogical results. Consider the third scenario set forth at the beginning of this Comment. It is quite possible that the parties will have absolutely no significant contact with the registry state apart froin their presence on the MSS; they may be ferried up to the station by a vehicle launched from elsewhere in the world. ${ }^{97}$ In such a case, soine other state's law might more logically govern the suit. ${ }^{98}$ Although the incident occurred "in the state," it is not intuitively obvious that registry state's laws should apply. ${ }^{99}$

A second disadvantage is the very minimization of discretion, which seems one of the most attractive features of the traditional approach. While restricting the discretion of the forum to choose the governing legal regime is probably wise, too stringent a restraint may cause the entire scheine to miscarry. The stricter the regime, the inore carefully will a court examine the outcome for injustice. It might then be tempted to ignore the rules altogether or to use a so-called escape device. ${ }^{100}$ For example, American courts will follow instructions in interuational litigation, whether given by the parties themselves ${ }^{101}$ or by statutes, as to

94. See, e.g., Argument for Petitioner at 361, Thompson v. Lucas, 252 U.S. 358 (1920). Thus, if lex loci delicti must be used, the closest available analogy would mandate the application of the registry state's substantive municipal laws.

Article VIII of the Outer Space Treaty reserves jurisdiction and control of a registered space object to the registry state. See supra notes 66-67 and accompanying text. Because the exercise of territorial sovereignty over outer space is forbidden, I assume that if any "place" is to be attributed to an act on a registered MSS, article VIII would provide the only factor connecting that act to an earthbound state. Thus, the lex loci delicti would be considered the registry state.

95. See Chung Chi Cheung v. Rex, 62 Lloyd's Rep. 151, 152 (1938); Caron, Ships, Nationality and Status, in 11 ENCYClopedia of PUblic InTERnational LAW 289, 289-90 (1989).

96. DeSaussure \& Haanappel, A Unified Multinational Approach to the Application of Tort and Contract Principles to Outer Space, 6 SYRACUSE J. INT'L L. \& CoM. 1, 12 (1978).

97. This would be likely if the space station had been in operation for some time, or if the station was built or assembled in outer space and not launched from the United States.

98. This, of course, is the position of those scholars, generally working in the United States, who have attempted to reform conficts of laws approaches. See infra text accompanying notes 11635.

99. The motivation for not employing registry state law would be even stronger were both parties of the same nationality but not citizens of the registry state.

100. See infra note 102.

101. For example, the U.S. Supreme Court upheld a choice of law clause in The Bremen v. 
which state's laws are applicable in various situations. However, if following these choice of law guidelines would work an injustice according to the forum's standards, the forum might pay lip-service to the guidehines while it finds ways to circumvent them. ${ }^{102}$ For example, under the traditional approacli, a forum court should apply the law of state $Y$ wlien a plane happens to crasli in state $Y$ on which a resident of state $X$ was flying from his lome state to state $Z .{ }^{103}$ Considering factors like inconvenience to the plaintiff, this result seems less equitable tlian would the application of state $X$ 's laws.

\section{B. Modifications to the Traditional Approach}

In response to these difficulties and inequities, forum courts liave developed a number of "escape devices," whicl enable thein to "do justice" witllout overtly rejecting the rule of lex loci delicti.

\section{Renvoi}

Under the doctrine of renvoi, for example, the adjudicating body applies both the choice of law rules and the substantive law of the state in which the tort "occurred"-in the case of an MSS, the registry state. One commentator suggests that renvoi be used for events occurring in outer space. ${ }^{104}$ Retaining a lex loci delicti approach that incorporates renvoi seems advantageous: it provides predictability but with enougl1 flexibility to achieve equitable results. Although the forum must apply both the substantive and conflicts laws of the registry state under this approach, the forum may nonetlieless be able to consider tlie concerns of non-registry states in applying the registry state's clioice of law rules.

Zapata Off-Shore Co., 407 U.S. 1 (1972). Because Zapata involved a contract, it was easier for the Court to implement the choice of law clause than it would otherwise have been. The same would hold true for the proposed convention because it is essentially a contract, with states in the place of individual parties.

102. For instance, a court could invoke lex loci delicti choice of law rules for tort actions. It provides uniform results for similar events within a given state; it is easy to articulate and almost as easy to apply; and if all jurisdictions employ this rule, the plaintiff has no incentive to forum-shop.

However, the proliferation of so-called escape devices in traditional choice of law theory, such as the substance-procedure dichotomy or renvoi, see infra text accompanying notes 104-10, demonstrates that a court can and will undermine a rigid rule if it wishes to do so. A court may state that it applies the relevant foreign law to substantive questions and local law to procedural issues, then characterize a substantive issue as "procedural" in order to apply local law. Or, using renvoi, a court may use the "whole" law-the conflicts of law rules as well as the substantive laws-of the foreign jurisdiction, which may well refer the court back to its own local law. R. CRAMTON, D. CURRIE \& H. KAY, supra note 92, at 65-66.

103. Cf. Alabama Great S. R.R. v. Carroll, 97 Ala. 126, 11 So. 803 (1892) (applying Mississippi law to a case in which the plaintiff, a citizen of Alabama, was injured on an Alabama train passing through Mississippi, even though this result denied recovery available under Alabama law).

104. Eisenstein, Choice of Law Regarding Private Activities in Outer Space: A Suggested Approach, 16 CAL. W. INT'L L.J. 282, $297-98$ (1986). 
Using renvoi as a choice of law approach poses several problems, however. First, if the registry state does not follow the traditional choice of law approach, renvoi makes the forum's eventual decision as unpredictable as it would have been had the forum openly discarded the lex loci delicti.

For example, if the registry state is the United States and the forum uses renvoi, the forum would try to follow American conflicts law. An American court would probably use an interest analysis considering and weighing several factors, ${ }^{105}$ including the place of the wrongful act, ${ }^{106}$ the law of the registry state (the United States), the donicile of the plaintiff (for exaniple, France), the domicile of the defendant or alleged wrongdoer (for example, Canada), the inaccessibility of a foreign forum, and the law of that forum. ${ }^{107}$ Applying American conflicts rules, the forum would eventually apply either American, French, or Canadian law, depending on the result of its own interest analysis. A niere reference to the whole law of the United States thus would not determine with any certainty the substantive law that eventually would be applied.

Second, the forum might not have ready access to the registry state's choice of law rules and might refuse to hear the suit or dismiss it on those grounds. ${ }^{108}$ Of course, all registry states could be required to deposit

105. Most of the courts within the United States use some form of interest analysis in determining which foreign law to apply. States in the United States that still adhere to the traditional rule are: Alabama, see, e.g., Powell v. Sappington, 495 So.2d 569 (Ala. 1986); Delaware, see, e.g., Friday v. Smoot, 58 Del. 488, 211 A.2d 594 (1965); Georgia, see, e.g., Ellington v. Tolar Constr. Co., 142 Ga. App. 218, 235 S.E.2d 729 (1977); Kansas, see, e.g., Brown v. Kleen Kut Mfg. Co., 238 Kan. 642, 714 P.2d 942 (1986); Maryland, see, e.g., Hauch v. Connor, 295 Md. 120, 453 A.2d 1207 (1983); Massachusetts, see, e.g., Pevoski v. Pevoski, 371 Mass. 358, 358 N.E.2d 416 (1976); Nebraska, see, e.g., Crossley v. Pacific Employers Ins. Co., 198 Neb. 26, 251 N.W.2d 383 (1977); South Dakota, see, e.g., First Nat'l Bank of Minneapolis v. Kehn Ranch, 394 N.W.2d 709 (S.D. 1986); Tennessee, see, e.g., Great Am. Ins. Co. v. Hartford Accident \& Indem. Co., 519 S.W.2d 579 (Tenn. 1975); Utah, see, e.g., Jacobsen v. Bunker, 699 P.2d 1208 (Utah 1985); Vermont, see, e.g., Burrington v. Ashland Oil, 134 Vt. 211, 356 A.2d 506 (1976); Virginia, see, e.g., McMillan v. McMillan, 219 Va. 1127, 253 S.E.2d 662 (1979); West Virginia, see, e.g., Carr v. Carr, 375 S.E.2d 190 (W. Va. 1988); and Wyoming, see, e.g., Duke v. Housen, 589 P.2d 334 (Wyo. 1979). Each of the other states has adopted one of the more modern approaches. For a general discussion of those approaches, see R. CRAMTON, D. CURRIE \& H. KAX, supra note 92, at 226-27, 305-08.

106. See supra note 79 and accompanying text.

107. See, e.g., Hellenic Lines Ltd. v. Rhoditis, 398 U.S. 306, 308 (1970) (noting factors set forth in Lauritzen v. Larsen, 345 U.S. 571, 583-91 (1952)).

108. In order to put an object into geostationary orbit, the object must be launched at or near the equator. The U.S., for example, lauuches its space objects from Cape Canaveral in Florida. The ESA, on the other hand, must launch its spacc objects from African states, which are much closer to the Equator than are its member states. The Registration Convention provides: "When a space object is launched into earth orbit or beyond, the launching state shall register the space object by means of an entry in an appropriate registry which it shall maintain." Registration Convention, supra note 64 , art. II, $\S 1,28$ U.S.T. 695,698 , T.I.A.S. No. 8480, at 4, 1023 U.N.T.S. 15, 17. The Convention defines "launching State" as a state "which launches or procures the launching of a space object" or "from whose territory or facility a space object is launched." Id: art. I, 28 U.S.T. at 698, T.I.A.S. No. 8480 , at 4, 1023 U.N.T.S. at 17. Consequently, either the African state or the ESA 
statements of their choice of law procedures with some central organization for reference, or the forum could use expert opinions to determine the registry state's choice of law methods. ${ }^{109}$ This clearly complicates rather than simplifies the forum's task and makes its determination of the governing substantive law no more predictable.

Third, a forum may feel unable to apply a registry state's conflict of laws rules for either policy or competence reasons. If the forum applies lex loci delicti and the registry state does not, the forum may not be confident of its ability to follow the registry state's choice of law approacli. If, on the other hand, the registry state applies lex loci delicti while the forum uses (for example) imterest analysis, the forum may feel competent but unwilling to bimd itself to an approach it has already abandoned in non-international cases. In some cases, these concerns might even induce the forum to disiniss the plaintiff's suit on the grounds of forum non conveniens. ${ }^{10}$

\section{Other Devices}

A second device is cliaracterization, which operates as follows: If, for example, the forum could cliaracterize the underlying action as one involving a contract imstead of a tort, it could apply the law of the state in which the contract was formed, if it considered that law more favorable than the law of the state in which the mjury occurred. ${ }^{111} \mathrm{~A}$ third related method is to distinguish substantive laws from procedural laws. Since the forum is only bound to apply the registry state's substantive laws (unless it employs renvoi), it could describe disagreeable portions of the registry state's laws as "procedural" and apply its own laws. ${ }^{12}$ Under botll the characterization and the substantive-procedural method, the

member may register the space object. See id. art. II, $\S 2,28$ U.S.T. at 699, T.I.A.S. No. 8480, at 5, 1023 U.N.T.S. at 17. If the African state registers the space object, its law-as the law of the registry state-may be the governing law. All the potential fora may not have ready access to the relevant African choice of law statutes and cases.

109. Although this seems more a question of the burden of proof than conflict of laws, it is proper to consider the difficulties associated with one course of action when comparing its merits to another.

110. This may not be terribly likely, as the existence of an international pact would presumably carry grcat weight in persuading the forum court to retain the suit, as would considerations of international relations and comity. See, e.g., Romero v. International Terninal Operating Co., 358 U.S. 354, 383 (1959) ("The controlling considerations are the interacting interests of the United States and of foreign countries, and in assessing them we must move with the circumspection appropriate when this Court is adjudicating issues inevitably entangled in the conduct of our international relations.").

111. In the plane crash example, see supra text accompanying note 103, the forum might characterize the plaintiff's right as contractual, based on the purchase of her ticket in state $X$, rather than as a tort.

112. For example, if state $Y$ in the plane crash example imposed a limit on damages, the forum might characterize damages as part of the remedy and thus procedural, not substantive. See, e.g., Kilberg v. Northcast Airlines, 9 N.Y.2d 34, 172 N.E.2d 526, 211 N.Y.S.2d 133 (1961) (measure of 
forum has almost unfettered discretion; almost no objective standards seem to apply to the forum's decision. ${ }^{113}$

A fourth method of avoiding traditional choice of law methodology is to find that applying the foreign state's substantive law would violate a strong public policy of the forum. ${ }^{114}$ For exainple, if part of state $Y$ 's laws were objectionable - they limited the plaintiff's recovery to a noininal ainount-the forum would be likely to declare that the limitation on damages was agaimst public pohicy and refuse to apply it. ${ }^{115}$ Again, however, the forum has broad discretion to determine what coinprises "strong public policy," which leads to an increased risk of uncertain results and abuse of discretion.

\section{Modern Alternative Approaches}

Several American scholars were disturbed by the often undisciplined use of these devices to evade the lex loci delicti approach. ${ }^{116}$ Accordingly, they proposed alternatives to the traditional rule, which seemed less erratic and more open than the judicially manufactured system of exceptions to lex loci delicti. ${ }^{117}$ But, all these alternatives share one initial drawback: the Umited States has been essentially the only state to have adopted these substantial innovations in choice of law theory. ${ }^{118}$

This Section discusses the two most influential and widely used alternatives in the Uinted States, "governmental interest analysis" and the "most significant relationship" test, ${ }^{119}$ and describes a third that

damages for wrongful death in Massachusetts is a procedural question controlled by policies of New York as law of forum).

113. See R. CRAmton, D. Currie \& H. KaY, supra note 92, at 90-94, 103-08.

114. See, e.g., Great Am. Ins. Co. v. Hartford Accident \& Indem. Co., 519 S.W.2d 579 (1975) (acknowledging approach that takes public policy into consideration but refusing to apply it in that case). The public policy concerns surrounding jurisdiction and effective control over ships flying flags of convenience provide a parallel example from maritime law. See, e.g., Osieke, Flags of Convenience Vessels: Recent Developments, 73 AM. J. INT'L L. 604 (1979) (discussing problems with and attempts to exercise more control over ships flying flags of convenience).

115. This does not mean, however, that the forum will automatically apply its own laws to the determination of hability. Dépeçage, discussed at supra note 2, allows the forum to split the issues in a case.

116. See, e.g., R. LeflaR, L. MCDougal \& R. Felix, American Conflicts Law 264 (1986).

117. See generally R. CRAMTON, D. CURRIE \& H. KAY, supra note 92 , at 136.352 (discussing alteruative modern approaches). Although the results of the alternative methods may not havc differed much from those of the traditional system when escape devices were invoked, these scholars felt that the alternatives captured more of the process that the courts should and often did employ. Id.

118. Other states recently have begun to investigate the advantages of some of these new approaches. See supra text accompanying notes 89-90.

119. See R. Cramton, D. CurRIE \& H. Kay, supra note 92, at 305-08. 
has been suggested for outer space torts, "comprehensive interest analysis." 120

\section{Governmental Interest Analysis}

Under Professor Currie's governmental interest analysis, ${ }^{121}$ the forum analyzes the justifications for laws the legislatures in question have passed in order to identify the policies singled out as important by those legislatures. ${ }^{122}$ If applying a jurisdiction's laws to the case at liand advances that jurisdiction's policies, then it lias a cognizable "interest" and its laws may be applied. ${ }^{123}$ If there is inore than one "interested" jurisdiction, the case presents a "true conflict." 124 In that case, the forum slould apply its own substantive law since a court should not intrude on the legislative domain by "'weigl[[ing]' the coinpetmg imterests, or evaluat[ing] their relative merits."125

Otlier scholars have rejected Currie's approach to true conflicts, ${ }^{126}$ objecting most often that Currie's preference for the law of the forum encourages "forum-shopping." In otlier words, the plaintiff lias an incentive to file suit in the forum that will give lier the most favorable law. Slie could even bring suit in a forum completely unconnected with any of the parties or issues involved in the dispute, if the forum could get personal jurisdiction over tlie defendant. There is little to recoinmend an approacl that allows a disimterested forum's substantive laws to control the outcome of a multijurisdictional case. ${ }^{127}$

On the other liand, as Professor Currie poimts out, courts-as nonrepresentative bodies-probably sliould not be allowed to weigh one jurisdiction's interests against another's and determine which are the

120. See Comment, supra note 44 , at $773-80$.

121. B. CURR1E, SELECTEd ESSAYS ON THE CONFL1CT OF LAWS 181-82 (1963).

122. Id. at 183-84. For example, a law imposing strict liability for injuries due to defective autonobiles presumably would imply that the legislature in question decided that protecting and compensatimg victims of car injuries was inore inportant than fostering the growth of the automobile industry (or so runs the argument against strict liability).

123. Id. When only one jurisdiction has an interest, there is a "false conflict." In that case, the foruin obviously applies the law of that interested jurisdiction. Id. at 183-84.

124. Id.

125. Id. at 181. Currie, however, einphasized that the forum should construe the laws so as to avoid "true conflicts" wherever possible. Currie, The Disinterested Third State, 28 LAw \& CONTEMP. PROBS. 754, 769-72 (1963).

126. See, eg., Baxter, Choice of Law and the Federal System, 16 STAN. L. REv. 1, 18-22 (1963) (arguing that Currie's theory is unsatisfactory because his objections apply equally well to court adjudication in general); Hill, Governmental Interest and the Confict of Laws-A Reply to Professor Currie, 27 U. CHI. L. REv. 463, 474-77 (1960) (pointing out some internal inconsistencies in Currie's theory); Von Mehren, Book Review, 17 J. LEGAL ED. 91, $92-97$ (1964) (criticizing Currie's assumptions and metlodology).

127. See R. CRAmton, D. CuRrie \& H. KaY, supra note 92, at 277-80 (finding that the application of the disinterested forum's laws inight occur in very limited circumstances). 
most important. ${ }^{128}$ This criticism is especially pertinent where no clear guidelines regulate the court's analysis of the interests in question.

\section{2. "Most Significant Relationship"}

The Second Restatement of Conflict of Laws, on the other hand, lists several factors to consider in determining which jurisdiction has the "most significant relationship" to botli the occurrence and the parties, and thus sliould have its laws apphed. ${ }^{129}$ In contrast to governmental imterest analysis, the forum here is given some guidance as to what factors should be considered in choosing the appropriate substantive law. At the same time, the forum retains the advantage of considering policy issues.

The goal of the approach is not merely to tally the number of contacts on eacli side, but rather to use the enumerated factors to determine the policies at stake. However, some coinmentators fear that mere contact-counting will subsume tlie policy analysis. ${ }^{130}$ Moreover, while the Restatement's approacl provides some recoininendations as to which types of policies a forum should weiglı in determining the appropriate substantive law, it-like Currie's governmental interest analysis-furmishes no principled criteria by which to decide the outcoine of specific policy conflicts. ${ }^{131}$

\section{Comprehensive Interest Analysis}

One non-traditional choice of law theory that has been suggested for outer space torts is comprehensive interest analysis. ${ }^{132}$ A forum einploying this theory would consider all the relevant interests at stake, including the interests of states whose nationals or property are not involved in the matter at liand, in determining the appropriate rule of law. ${ }^{133}$ If the forum found no existing law appropriate, it could create an entirely new substantive rule of law which accommodated the various interests. ${ }^{134}$

128. B. CURRIE, supra note 121 , at 181 .

129. RESTATEMENT, supra note $79, \S \S 6,145$.

130. See, e.g., R. WEINTRAub, COMMENTARY ON THE Conflict of Laws 364 (2d ed. 1980).

131. See Von Mehren, Recent Trends in Choice-of-Law Methodology, 60 CORNELL L. REV. 927, 964 (1975).

132. Professor Luther McDougal is the chief proponent of this theory. See McDougal, Comprehensive Interest Analysis Versus Reformulated Governmental Interest Analysis: An Appraisal in the Context of Choice-of-Law Problems Concerning Contributory and Comparative Negligence, 26 UClA L. Rev. 439 (1979); McDougal, Choice of Law: Prologue to a Viable Interest-Analysis Theory, 51 Tul. L. REv. 207 (1977); Comment, supra note 44, at 773-80; see also Comment, supra note 10, at $1947-48$.

133. Comment, supra note 44 , at 774. These interests would include those of the victim, the defendant, their respective states, and other states and their nationals who would be affected by the dispute and its resolution.

134. Id. at 774-75. 
This recommended theory has two advantages: it allows space jurisprudence to meet the participants' actual needs, and it infuses flexibility into a court's apphication of earthbound law to outer space ventures. However, it has the disadvantage of giving the forum hearing the case an inordinate amount of lawinaking authority. The court's determination that the existing law is inadequate and formulation of a new rule of law are not, by definition, actions subject to the constraints of ordinary adjudication. As a result, the decision could be criticized as unduly favoring one party, even if it was in fact impartial.

Moreover, states tend to be very jealous of their sovereignty. They may be reluctant to subinit to the laws of another state; ${ }^{135}$ they may be even more reluctant to agree to a choice of law method that required them to submit to law created out of whole cloth by the courts of another state. A party could thus have difficulty enforcing such a judgment outside the forum state. A party could also have difficulty using decisions reached under comprehensive interest analysis by the court(s) of one state as precedent in the courts of another.

\section{Registration By International Organizations}

Yet another possible choice of law approach would be based on the registration of an MSS by an international orgamization, rather than by a single state. The analogous possibility of ship registration by international organizations has sparked interest among commentators in maritime law. ${ }^{136}$ For outer space, one could give jurisdiction and control over an MSS and its crew to an international orgamzation. This procedure seems to preserve the clarity of a "registry state" choice of law principle without shortchanging the concerns of non-registry states for their nationals. Allowing international organizations to register an MSS in comphiance with the Convention would also reduce (though not eliminate) the problem of inconsistency among the laws of individual states. ${ }^{137}$

Unfortunately, the member states of an organization retam their individual legal systems; thus, there would be no uniform multimational

135. See Comment, supra note 10 , at 1947.

136. See, e.g., A. Limitone, The Registration of Ships BY INTERNATional ANd InTERgovernmental Organizations (University of Miami Sea Grant Program, NOAA Sea Grant No. 2-35147 (1971)); Caron, supra note 95, at 29496.

137. What type of international organization do commentators have in mind? For example, states might not be able to build and/or finance a space station individually. Their joinder as an organization would create an entity with the resources to do so. $C f$. A. LIMrrone, supra note 136, at 19 (financing research and development for a nuclear-powered ship). Smaller countries could participate in outer space activities without being restricted to partnerships with larger countries.

In deciding on a legal regine to govern such an MSS, the states involved may be averse to registering the station with any one of the individual member states, $c f$. id., or may be unable to agree upon one governing set of laws. Registering the station with the organization itself would presuinably resolve these issues. 
law applicable to the situation. But the existence of the association would increase the likelihood that a form of dispute resolution binding on the meinber states (including, presunnably, their nationals) could exist. ${ }^{138}$

The actions of the Umited Nations serve as the principal example of ship registration by an international organization. On several occasions, the Umited Nations has sailed ships under the U.N. flag, ${ }^{139}$ which miglit serve as a inodel for solving clioice of law problems. An international body could be established to control the use of outer space and to serve as the state of registry for space vehicles. The organization itself would promulgate regulations governing multinational space stations; ${ }^{140}$ its meinber states would appoint ineinbers to coininittees to draft rules, and would liave the right to vote-and by inplication have an influence on the content of those regulations. ${ }^{141}$

There are nonetlieless several difficulties witl allowing an international organization to register an MSS. First, although ineinbership could be limited to MSS participants, each state iniglt not have an equal voice in the organization. ${ }^{142}$ Sucl1 power imbalances may affect the ability of the organization to represent all its meinbers effectively. Furthermore, even if states agreed to becoine inembers of sucli a nongoverninental organization, they imglit be unwilling to cede autonoiny or power to it.

Second, the question of what substantive law should apply to internationally registered ships and their crews has never been resolved. Ideally, the international organization would follow the "flag state" choice of law primciple prevailing in inaritime law and apply the organization's own laws. However, in actual practice this has not been the case. For example, during the 1956 Suez Crisis, eacli state represented in the U.N.

138. For example, ESA members must submit disputes among the member states or between a member and the ESA itself to arbitration. European Space Agency Convention, supra note 85, art. XVII, 14 I.L.M. at 881 .

139. Caron, supra note 95, at 294. Apparently, the legality of this practice has not been settled. A. Limtrone, supra note 136, at 13; Caron, supra note 95, at 294-96. Registration by an international organization, however, is not ruled out by the Law of the Sea Convention, supra note 31 , art. 7, 13 U.S.T. 2312, 2315, 450 U.N.T.S. 82, 86 ("The provisions of the preceding articles do not prejudice the question of ships employed on the official service of an inter-governinental organization flying the flag of the organization."). The Registration Convention, in contrast, expressly provides, subject to certain conditions, that "any international intergovernmental organization which conducts space activities" ean register space objects. Registration Convention, supra note 64 , art. VII, 28 U.S.T. 695 , 701, T.I.A.S. No. 8480 , at 7, 1023 U.N.T.S. $15,18$.

140. Note that the U.N. does not have laws governing hability and damages, nor, presumably, would a space organization.

141. For a proposal to make a state's influence on international agreements concerning such issues as planetary exploration proportional to that state's importance in the area, see Danilenko, Outer Space and the Multilateral Treaty-Making Process, 4 High TECH. L.J. 217 (1989).

142. Id. at 229-32. 
Emergency Force governed the conduct of its nationals by its own criminal laws. ${ }^{143}$ Since the Umited Nations does not have a criminal code of its own, that choice may have been mevitable. Thus, broadening the definition of "registry state" or "flag state" to mclude international organizations offers no advantages unless the orgamization in question already has a choice of law protocol im place or unless a separate dispute-resolving body is available.

Third, the extent of the international organization's authority over an MSS nay be unclear. When the United Nations has sailed ships, each ship either flew the U.N. flag alone (but continued to possess the nationahty of a particular state), or flew the U.N. flag ni conjunction with the flag of the state from which it was chartered. ${ }^{144}$ It is unclear whether the U.N. flag was used simply as identification or as an indication that the full panoply of U.N. laws apphed. ${ }^{145}$ Moreover, each time the United Nations allowed these ships to fly its flag, emergency conditions existed and the duration of the U.N. flag's use was limited. ${ }^{146}$ As a result, the use of the U.N. flag may have been acceptable only because of the exigent circumstances, and using an international organization as registry state may turn out to be impermissible on a permanent or seimi-permanent basis.

\section{E. Maritime Choice of Law Practice}

One choice of law approach that has received relatively hittle attention from the commentators in the field of conflict of laws is maritime choice of law. Nonetheless, inaritime choice of law principles provide an attractive alternative to the more widely known approaches. The argunent for using maritime practice as a paradigm for space station choice of law draws much of its power from the similarities between a ship on the high seas and a space station orbiting the Earth. ${ }^{147}$ Unlike the crew of an airplane, for example, the crews of both ship and space station live

143. This was provided for in the U.N. Emergency Force Regulations. A. LIMrTone, supra note 136, at 21-22. During the Suez Crisis, there was probably little, if any, mixing of nationalities within units. Cf. Caron, supra note 95, at 295 (U.N. land forces have generally consisted of national units integrated by an international command). A United Nations naval force would likely be arranged in order to protect the crew and vessels, to ensure that the crew operated as a team, and to facilitate crew communication. Id. However, in the case of a space station, where individuals of different nationalities will hive in close proximity for extended periods of time, other factors may come into play.

144. Caron, supra note 95, at 295.

145. Id.

146. See id. at 294.

147. Although an analogy to Antarctica might be relevant here, I will not discuss Antarctica because, as discussed at supra notes 19-28 and accompanying text, there is no uniform legal regime in Antarctica-inunicipal or international-that would provide a model for choice of law rules. 
(or will live) in a closed community for extended periods of time. ${ }^{148}$ The crewinembers are cut off from the general population, and they depend on each person to perform his or her duties in order to prevent disasters. Most importantly, the territory a ship or a space station traverses is not subject to any one state's exclusive jurisdiction; botll the high seas and outer space are res communis. ${ }^{149}$ Maritime law thus would seem a fruitful and acceptable source of clioice of law rules for incidents involving MSS personnel.

\section{Choice of Law Principles in Maritime Tort Law}

The inaritime inodel's solution to the choice of law question prescribes that the law of the flag state will govern incidents occurring aboard a ship ${ }^{150}$ that affect only the ship or its crew while it plies the high seas. ${ }^{151}$ This ensures that, at least on the ligh seas, a single consistent set of substantive laws governs the conduct of a ship and its crew. Such a uniform legal regime would also benefit the crew of an MSS.

Nevertheless, it may arise that two (or more) states could claim that their laws regulate the conduct of a crewmember who is a national of one state but who serves aboard a ship flying the flag of another state. Despite tliese concerns, the customary maritime rule is still to make a ship's flag the controlling factor in ascertaining which state's substantive laws control. ${ }^{152}$

148. See, e.g., DeSaussure, supra note 10, at $991-93$ (concluding that living and working on board space stations should become routine by the year 2000 and that a legal regime will be necessary to govern "community living" in space); DeSaussure, Toward a Law for Space Transport: The Maritime Analogy, 14 LiNCoLN L. REV. 1, 1-2 (1983) (stating that space shuttle fights will resemble ocean voyages in terms of duration, with some missions lasting weeks or more); DeSaussure, Maritime and Space Law: Comparisons and Contrasts, 9 J. SPACE L. 93, 100-01 (1981) (anticipating space voyages of long duration). A more apt analogy might be between the crew of Jacques Cousteau's ship Calypso and the personnel aboard a space station. Both groups are engaged in research, working in close quarters, and working with colleagues from around the world.

149. See J. Kish, THE LAw OF INTERnATIONAL Spaces 54-60, 82-89 (1973).

150. The captain and crew of a ship, for example, are subject to the law of the ship's flag state for actions committed on the high seas. See, e.g., R. RoDière, Drort Maritime 19 61-62 (1969) (because there is no applicable territorial law, the captain and crew can only be held liable according to the law of the ship's nationality). Although the law applicable to passengers on a ship is usually determined by the terms of the contract for carriage (the ticket), there is a prima facie inference that it is the law of the state in which the contract was formed. 43 HALSBURY's LAwS OF ENGLAND Shipping and Navigation If 806 (Lord Hailsham 4th ed. 1983). I will leave discussion of passengers on space stations for another time.

151. See, e.g., United States v. Flores, 289 U.S. 137, 158-59 (1933) (holding that incidents on board a ship which affect only the vessel should be left to the authority of the nation to which the vessel belongs); see also 2 E. RABEL, supra note 79, at 336-40 (although the lex loci delicti rule governs collisions in ports or internal waters, the law of the flag governs most incidents on the high seas).

152. See, e.g., Chartered Mercantile Bank of India v. Netherlands Steam Navigation Co., 10 Q.B.D. 521, 524 (1883) (holding that the rights of the parties on a ship are determined by the ship's flag); The Queen v. Anderson, 1 L.R.-Cr. Cas. Res. 161 (1868) (Anerican serving on British ship 


\section{Drawbacks of Maritime Choice of Law Principles}

Despite the parallels, we should be wary of applying any relevant maritime law-directly or by analogy-to the problem of choice of law for incidents involving MSS personnel for several reasons.

First, analyzing the problein anew instead of simply adopting inaritime law gives the MSS's planners an opportunity to correct any flaws in the ship-on-the-high-seas model, or to change any facets of the model that they find unsatisfactory. Such changes could include provisions for areas of law that the maritime law does not cover; ${ }^{153}$ other changes could include explicit provisions granting inore power to international orgamizations, ${ }^{154}$ or setting forth a forum court's duties.

Moreover, many states now active in utilizing outer space have had little influence on the development of maritime law..$^{\text {15s }}$ Such states probably deserve-and want-a larger role in developing space law. Simply imposing maritime law on states that did not have a hand in shaping that

who caused death of another American serving on same ship was subject to the jurisdiction and substantive law of Britain); Merchant Shipping Act of 1894, 57 \& 58 Vict. ch. $60, \S 265$ (if there is no express determination of the appropriate substantive law, the law of the port of registry applies); see also 8 HALSBury's LAws of ENgLAND Conflicts of Law I 625 (Lord Halisham 4th ed. 1974); P. North, Cheshire's Private INTERNational LaW 290-92 (10th ed. 1979).

153. If a scientist-or anyone stationed on the MSS-invented something, which state's intellectual property laws would protect that invention? the inventor's? the registry state's? See generally Meyer, Protecting Inventors' Rights Aboard an International Space Station, 70 J. PAT. \& TRADEMARK OFF. SOC'Y 332 (1988) (proposing a systern for determining which patent laws should apply to persons involved in research and development activities aboard a space station).

Another issue for which maritime law provides little guidance is the taxation of goods produced on an MSS. This is hardly an obscure question, as outer space may quickly become a profitable manufacturing site. See, e.g., Galileo Sent on Way, Atlantis Returns, N.Y. Times, Oct. 24, 1989, at C7, col. 6; Private Space Projects Lagging, N.Y. Times, June 1, 1989, at D1, cols. 2-3 (space-made molecules and crystals with undistorted structure have great commercial potential); Shuttle Experiments Seek Clues to Building Blocks of Life, N.Y. Times, Mar. 14, 1989, at Cl, col. 5 (protein crystals growu in space have potential to be "first busimess success story"); Made in Space, N.Y. Times, May 19, 1987, at C8, col. 5 (polystyrene microspheres sold as reference standards were manufactured aboard the space shuttle Challenger); Hailstorm Damages Shuttle, N.Y. Times, June 27, 1982, § A1, at 26, col. 3 (latex microspheres manufactured aboard space shuttle Columbia sold for $\$ 608$ per teaspoon). Many European countries collect a tax (value-added tax, or VAT) at every step in the manufacturing process where "value" is added to the product. Sernau, The Foreign Sales Corporation Legislation: A 510 Billion Boondoggle, 71 CoRnell L. Rev. 1181, 1183 (1986). The United States has established a $3.75 \%$ tax on the imputed value of lard inineral resources mined from the sea bed, 26 U.S.C. $\S 4495$ (1988); 30 U.S.C. $\S 1472$ (1988), but this tax is imposed on resources reinoved from the sea, not goods produced from raw unaterials or components, and thus provides little guidance for goods manufactured in space. It could, lowever, serve as the basis for an analogous tax on resources discovered in space.

154. See supra text accompanying notes $136-46$.

155. Present-day maritime law has its roots in Western European culture. See E. GoLD, Maritime Transport: The Evolution of International Marine Policy and Shipping LAw 98-100 (1981). Non-European states have generally adopted those principles of maritime law, see, e.g., P. SolodovNIKofF, LA NAVIGATION MARITIME DANS LA DOCTRINE ET LA PRATIQUE SoviETIQUES (1980), despite their lack of input into the developnent of these primciples. However, the development of outer space law should be responsive to the needs of those states most active in 
law would be unfair; they would have no chance to voice their particular concerns regarding the use of outer space. Those who are to be subject to laws should be able to decide the contents of those laws. ${ }^{156}$ Policy considerations suggest that maritime law should not be apphied wholesale, despite the help it supphies in searching for an appropriate choice of law rule for torts involving MSS personnel.

In addition to policy concerns, the analogy itself breaks down in several key areas. The procedure by which a ship is accorded a "nationality" differs in several ways from the "registration" of a space object by a state. Strict apphication of maritime law nay thus be impracticable and undesirable. In particular, application of maritime law may conflict with provisions of the Registration Convention.

One difference between the two procedures involves the coinpulsory nature of granting a vessel the protection of a state's laws. A ship need not have a nationality, that is, it may be stateless. Although such a situation may cause difficulties, it is not unlawful per se. ${ }^{157}$ The Registration Convention, however, declares that "[w] hen a space object is launched into earth orbit or beyond, the lannching state shall register the space object."158 A space station thus is much less likely than a ship to be "stateless"; in fact, the result seeins impossible for signatories of the Registration Convention. If traditional maritime choice of law principles were blindly followed for an MSS, the registry state would autoinatically be granted exclusive jurisdiction. ${ }^{159}$ Consequently, if a state owning an MSS module did not want to limit the governing law to one state's scheme, it would be forced to escape the registration requireinent by refusing to sign the Registration Convention.

In addition, space law may provide stricter controls than niaritime law on which state's laws may be applicable under the principle of law of the registry (or flag) state. In maritime law, each state may set its own conditions for granting a ship a "nationality."160 Many states require

outer space, which include the United States, the Soviet Urion, the inember states of the ESA, and Japan.

156. Of course, if a nation disliked the substantive content of the proposed convention, it could simply refuse to sign. This refusal might resnlt in either (1) an inability to take part in missions carried out aboard space stations (if the other nations made acquiescence a condition to participation), or (2) an incentive to sign the convention and then try to evade its results (on grounds of local public policy).

157. Caron, supra note 95, at 293-96; see also High Seas Convention, supra note 31, art. 6(1), 13 U.S.T. 2312, 2315, 450 U.N.T.S. 82, 86 ("Ships shall sail under the flag of one State only and . . . shall be subject to its exclusive jurisdiction on the high seas. . . A ship which sails under the flags of two or inore States ... inay be assinilated to a ship without nationality.").

158. Registration Convention, supra note 64, art. II, § 1, 28 U.S.T. 695, 698, T.I.A.S. No. 8480, at 4, 1023 U.N.T.S. 15, 17 (emphasis added).

159. See supra text accompanying note 32 .

160. Lauritzen v. Larsen, 345 U.S. 571, 584 (1953). 
some form of "genuine link" between the flag state and the ship" 161 but do not define what constitutes that "link." By contrast, the Registration Convention explicitly defines states qualified to register an MSS"launching states"-as those states which launch or procure the launching of the station, or from whose territory or facility the station is launched. ${ }^{162}$ Unless "procuring" a launch is construed broadly, the legal regime of an MSS might be limited to the substantive laws of the few states having the capability to launch space objects.

Furthermore, if there are two or more launching states, they jointly decide "which one of them shall register the [space] object."163 This phrase apparently is a requirement that only one state register an MSS. However, the Convention immediately goes on to provide that the launching states may make separate agreements as to "jurisdiction and control," which will not be affected by the registration of the object by only one state. ${ }^{164}$ This possibility of joimt jurisdiction over an MSS (or portions thereof) despite registration by only one state would be precluded if maritime law were strictly apphed. ${ }^{165}$

\section{American Maritime Choice of Law}

A foruin could, alternatively, choose to apply some other set of substantive laws - the internal laws of the plaintiff's state or the defendant's state, for example. Such an approach may be more equitable for a number of reasons. If the registry state chooses to limit hability, for example, it seems unfair to apply the law of that state and enforce that choice, when it would leave the plaintiff with little or no reparation. ${ }^{166}$

161. The Convention on the High Seas requires such a "geuuine link." High Seas Convention, supra uote 31 , art. 5, $\S 1,13$ U.S.T. at 2315,450 U.N.T.S. at 84.

162. Registration Convention, supra note 64, art. I, 28 U.S.T. at 698, T.I.A.S. No. 8480 , at 4, 1023 U.N.T.S. at 17. However, ouly one of the (possibly several) states qualified to register an MSS inay do so. Id. art. II, 28 U.S.T. at $698-99$, T.I.A.S. No. 8480 , at $4-5,1023$ U.N.T.S. at 17.

163. Id. art. II, $\S 2,28$ U.S.T. at 699, T.I.A.S. No. 8480 , at 5, 1023 U.N.T.S. at 17.

164. Id., 28 U.S.T. at 699, T.I.A.S. No. 8480 , at 5, 1023 U.N.T.S. at 17.

165. Under maritine law, the flag state has exclusive jurisdiction over vessels fiying that flag while they ply the high seas. High Seas Couvention, supra note 31, art. 6, § 1, 13 U.S.T. at 2315, 450 U.N.T.S. at 86; Law of the Sea Convention, supra note 31, art. 92, $\S 1$. There are, however, some limitations on the flag state's exclusive jurisdiction on the high seas. Most importantly, in the event of collision, the nationality state of thc master of the ship possesses concurrent jurisdiction. Caron, supra note 95, at 293.

166. Cf. Lauritzen v. Larsen, 345 U.S. 571, 587 (1953) ("[I]t is common knowledge that in recent years a practice has grown, particularly among American shipowners, to avoid striugent shipping laws by seeking foreign registration eagerly offered by soine countries. Confronted with such operations, our courts on occasion have pressed beyond the formalities of inore or less nominal foreign registration to enforce against American shipowners the obligations which our law places upon them.") (footnotes omitted); see also Dimskal Shipping Co. S.A. v. International Transp. Workers Fed., 1 Lloyd's Rep. 166, 172 (1989) (contracts of employinent for Filipino crew on Panamanian ship not governed by law of flag but by systein of law with which the transactions have their closest connection). 
After all, the parties' expectations have probably been shaped by the norms of the legal system with which they are most familiar, and that legal system may not limit damages.

Moreover, when neither party is a national of the registry state, it would be unfair to force a party to be controlled by that state's laws. Tort law is aimed not only at compensating the plaintiff but also at settimg standards of conduct for all actors. If an individual does not know what the applicable standard is, it would be unjust to impose liability for actions she did not know were "wrong."

Given these considerations, it is not surprising that the U.S. Supreme Court has applied the traditional choice of law principles in maritime law in a modified form. ${ }^{167}$ Just as American conflict of laws scholars generally turned to forms of interest analysis because of their dissatisfaction with lex loci delicti, the Supreme Court shifted from a strict law-of-the-flag-state rule to an evaluation of various factors in determining the governing substantive law in maritime cases.

In Lauritzen v. Larsen, the Supreme Court stated that "[m]aritime law ... has attempted to avoid or resolve conflicts between competing laws by ascertaining and valuing points of contact between the transaction and the states or governinents whose competing laws are involved."168 The Court then histed seven factors that influence a forum's choice of law im maritime tort cases, and particularly in cases where a sailor sues the shipowner: the place of the wrongful act, the law of the flag, the allegiance of the plaimtiff, the domicile or allegiance of the defendant, the place where the employment contract was made, the inaccessibility of a foreign forum, and the law of the fornm. ${ }^{169}$

Nonetheless, the Court maintained that "the weight given to the [ship's flag] overbears most other connecting events in determining applicable law."170 The justification for such a practice is that "the territorial standard [for the application of laws] is so unfitted to an enterprise conducted under many territorial rules and under none that it is usually modified by the more constant law of the flag."171 However, the Supreme Court has refused to apply the law of the flag state when the

167. G. SUNDSTROM, THE EFFECT OF FOREIGN ELEMENTS IN COLLISION LITIGATIONS IN THE UNITED STATES 11 (1965) (stating that American courts hold that "since the general maritime law governs on the high seas, and since this is a part of the law of the forum [the U.S.], a collision on the high seas is analogous to a collision on American waters ... and therefore American law applies").

168. 345 U.S. at 582; see also Symeonides, Maritime Conflicts of Law from the Perspective of Modern Choice of Law Methodology, 7 MAR. LAw. 223, 238-40 (1982) (stating that the seven factors developed in Lauritzen provide the basis for resolution of maritime choice of law conficts, but have been expanded upon in later decisions).

169. Lauritzen, 345 U.S. at 583-93.

170. Id. at 585 .

171. Id. at 584 . 
circumstances so warrant. ${ }^{172}$

This modified version of maritime choice of law rules avoids the inflexibility of the lex loci delicti approach yet restrains the decisionmaker more than comprehensive interest analysis or even Currie's governmental interest analysis. In fact, this approach bears a strong resemblance to the "most significant relationship" approach. This modified maritime regime assigns greater importance to one factor (the flag state) than to the others, unlike the "most significant relationship" approach, and thus guides the forum in resolving conflicts between the policies of different states. However, there is still a danger that a forum will merely count up contacts, or even introduce its own hist of factors in determining the substantive law that should be applied.

\section{IV}

\section{A Proposal for Restricted INTERest ANALysis}

As we have seen, simply following the traditional rule and applying the registry state's laws is not the most desirable choice. Even so, it is unlikely that all the states mvolved im planning the space station would be willing to adopt full-scale interest analysis as a technique for ascertaining the governing substantive law. What modifications of the lex loci delicti might be tolerable for all the states involved?

Providing for some flexibility within the proposed convention itself as to what state's laws govern, while expressly hiniting the factors that the adjudicative body could consider, is the best solution to this problem. I propose a "restricted" interest analysis approach, under which the convention would set forth three factors that a forum could consider in determining the appropriate substantive law to apply. This approach is less rigid than the traditional lex loci delicti, yet more predictable than open-ended conventional interest analysis. I recommend that the choice of law methodology set forth in the proposed convention allow the tribunal to apply only the substantive law of the state of registry, that of the plaintiff's state, or that of the defendant's state.

I have drawn these factors from American maritime law, since a ship on the high seas bears so much resemblance to an MSS. As described above, the U.S. Supreme Court regards a ship's flag as the controlling factor in ascertaining which state's laws control in maritime law, absent countervailing considerations. ${ }^{173}$ The apphication of the registry

172. See, e.g., Hellenic Lines v. Rhoditis Ltd., 398 U.S. 306, 309-10 (1970) (court applied American law to the alien owner of a ship fiying Greek flag because the alien owner had substantial and continuing contacts with the U.S., which was its "base of operations").

173. See supra text accompanying note 170. Although the incident in Lauritzen occurred in Cuban territorial waters and not on the high seas, the Supreme Court expressly noted that shipping is "an enterprise conducted under inany territorial rules and under none." Id. at 584 (einphasis 
state's laws, by analogy, seems natural. The parties' nationalities, however, are also factors cited by the Court in determining the appropriate choice of law. ${ }^{174}$ The tribunal could thus choose to apply the internal laws of the plaintiff's state or the alleged tortfeasor's state.

This restricted interest analysis accommodates several pohicy considerations, the first being predictability. As inaritime law apphes the law of the flag state, applying the law of the registry state would lead to certainty about which state's laws would govern an incident aboard a space station. ${ }^{175}$ The forum would be bound to apply the registry state's laws regardless of other considerations.

Note, however, such predictability would often be achieved at the cost of fairness, the second pohicy consideration. If a Dane accidentally tripped another Dane in an MSS registered by the United States, why should American law govern-especially if the plaintiff does not bring a claim for compensation until she returns to Denmark? Insisting that American substantive law govern the plaintiff's compensation under those circumstances would be unjust.

Expectations, which have probably been shaped by the legal system of each party's home state, comprise the third policy consideration. Of course, unless both parties are from the saine state, one party's expectations will be unfulfilled if the tribunal applies the law of only one party's state. Moreover, when neither party is a national of the registry state, forcing both to be controlled by that state's laws seems equally unfair.

On the other hand, the longer personnel remain on the MSS, the more acceptable the application of the registry state's laws may become. Further, the Outer Space Treaty's terms can be interpreted as giving the registry state complete power over all activities in the station and thus all the consequences of those activities. ${ }^{176}$ This may very well include regulations that determine liability and damages for injuries due to negligent behavior.

The fourth policy consideration involves adequate compensation for the plaintiff. If the "launcling states" intentionally select a state that limits liability as the state of registry, ${ }^{177}$ it seems unfair to give effect to that limitation and leave the plaintiff witll little or no reparation, even if that limitation is the law of the registry state.

added). For that reason the Court gave the law of the flag state preeminence, refusing to apply American law.

174. See id. at 583-93 (enumerating seven factors that influence a forum's choice of law in maritime tort cases).

175. Incidents involving station personnel occurring outside an MSS-such as accidents occurring during a spacewalk or during a transfer of personnel or cargo from one space vessel to another-would not come under the provisions of such a rule.

176. See supra text aceompanying notes 66-69.

177. See supra text accompanying note 163 . 
Although a desire for predictability leads one to adopt general maritime law principles, other policy concerns suggest the desirability of modifying those principles for tlie outer space context. Traditional maritime choice of law does not sufficiently protect party expectations, or ensure adequate compensation for the plaintiff and fair treatment for all parties. A separate convention should adopt modified maritime law principles similar to the interest analysis adopted by the U.S. Supreme Court. ${ }^{178}$

Such an approach affords many advantages. Activities infrequently pursued on ships, and therefore overlooked in maritime law, may require special provisions in space law. A separate convention could safeguard these activities. In addition, negotiating the terms of a clioice of law convention for outer space torts would provide a unique opportunity to address whetler international organizations slould be treated on a par with states and allowed to register vessels. ${ }^{179}$ Moreover, a separate clioice of law convention would provide states that had little input into shaping maritime law witl an opportunity to lielp forn tlie legal regime by whicl they will be governed in outer space. ${ }^{180}$

Finally, a separate convention would ease any worries about directly applying maritime principles that miglit conflict with the Registration Convention, owing to technical differences between granting a ship nationality and registering an MSS. ${ }^{181}$ Although an MSS cannot be completely "stateless" as can a ship, ${ }^{182}$ the owner of an MSS or part tliereof still has some flexibihity in deciding whicl state's laws govern incidents aboard that MSS.

$\mathrm{V}$

The Role of an ARbitration Tribunal

The task of balancmg and carrying out these pohicy concerns and applying one of the aforementioned state's laws to any suit falling under the proposed convention's provisions should be entrusted to arbitrators, not inunicipal courts. ${ }^{183} \mathrm{I}$ recommend that the proposed convention

178. See supra note 174.

179. See supra text accompanying notes 136-46.

180. See supra text accompanying notes $155-56$.

181. See supra text accompanying notes 157-65.

182. See supra text accompanying notes 157-58.

183. The Space Station Agreement requires states party to the agreement to use "best efforts" to settle disputes among themselves through consultation, and allows them to agree to submit to arbitration. Space Station Agreement, supra note 9, art. 23; see Comment, supra note 10, at 1942. However, this provision does not resolve whether entities not party to the agreement must consult or submit to arbitration. 
incorporate the provisions of the UNCITRAL Model Law on International Commercial Arbitration ${ }^{184}$ in order to implenent the convention's choice of law stipulations. Those provisions are widely used and accepted by private parties engaged in international transactions. ${ }^{185}$

There are several reasons for preferring arbitration to suits in a state court systein. First, arbitration is inuch inore flexible than a judicial proceeding. The arbitrators can be chosen for their expertise in a field of law with concomitant shifts in the proceedings. Arbitration can also incorporate time constraints that would speed coinpensation to the plaintiff. The parties can agree on the procedural rules for arbitration, and can make additional agreeinents to govern the tribunal's deliberations.

Second, an arbitration panel nay be able to exercise jurisdiction over both of the parties. ${ }^{186}$ The Outer Space Treaty, as noted above, provides that the registry state "shall retain jurisdiction and control over [a space] object, and over any personnel thereof, while in outer space or on a celestial body." 187 A strict reading of the last clause would lead one to conclude that the registry state's jurisdiction ends when the object or the "persomiel thereof" leave space. ${ }^{188}$ The Space Station Agreement

184. UNCITRAL Model Law, supra note 16.

185. Although the UNCITRAI Model Law itself does not seem to have been applied to tort cases (as opposed to commercial disputes), a variety of personal injury disputes are resolved by arbitration in the United States. See, e.g., 9 U.S.C. $\$ 2$ (1988) (tort claims are not excluded from the scope of the Federal Arbitration Act); CAL. Civ. Proc. CoDE $\S \S 1141.10-1141.32$ (West 1982 \& 1990 Supp.) (California has legislatively encouraged the use of arbitration for medical malpractice claims); Edwards, Alternative Dispute Resolution: Panacea or Anathema?, 99 HARV. L. REv. 668, 673-74 (1986) (arbitration often compelled for tort claims with potential damage awards below a certain amount); Kanowitz, Altermative Dispute Resolution and the Public Interest: The Arbitratlon Experience, 38 HASTINGS L.J. 239, 290-91 (1987) (arbitration of medical malpractice claims often compelled by statute). But cf. Simon v. St. Elizabeth Medical Center, 3 Ohio Op. 3d 164, 355 N.E.2d 903 (C.P. 1976) (compulsory arbitration of medical malpractice claims violates equal protection and due process). Of course, if the United States were to sign a liypothetical choice of law convention, those rules would supersede the laws of individual states. See U.S. CONST. art. VI. Arbitration could nonetheless probably not serve as an exclusive remedy because it would infringe upon the right to a jury trial in certain civil cases. Id. amend. VII.

186. A forum court's ability to exercise jurisdiction, on the other hand, will depend on the theory under which it operates. For example, if the forum operates on the territoriality theory, the plaintiff may not be able to recover damages unless a defendant is served with process while he or she is present in the forum state. However, if the forum employs a "contacts" test, as the United States does, a plaintiff could bring suit in a forum completely unconnected with the underlying incident as long as the defendant had other sufficient contacts with the forum. See, e.g., International Shoe Co. v. Washington, 326 U.S. 310 (1945).

187. Outer Space Treaty, supra note 17, art. VIII, 18 U.S.T. at 2416,610 U.N.T.S. at 209; see supra text accompanying notes 66-69; see also Beattie v. United States, 756 F.2d 91, 100 (D.C. Cir. 1984) (basic principle of the Outer Space Treaty is that "in the sovereignless reaches of outer space, each state party to the treaty will retain jurisdiction over its own objects and persons") (dicta).

188. Cf. 18 U.S.C. $\S 7(6)$ (1988), which defines "special maritime and territorial jurisdiction of the United States" to include:

Any vehicle used or designed for flight or navigation in space and on the registry of the

United States... while that vehicle is in flight, which is from the moment when all external 
gives a state party to the agreement jurisdiction and control over crewmembers who are its nationals and over MSS components that it has registered under the Registration Convention. ${ }^{189}$ Nonetheless, the agreement gives no guidance when more than one state may exercise jurisdiction. 190

These jurisdictional problems disappear if the dispute is brought to arbitration pursuant to the proposed convention. Thus, I propose that ratification of the proposed convention be a prerequisite to participation by a state in the MSS. In the case of an individual whose state has not ratified, the individual should be strongly encouraged to sign a contract that contains the choice of law and arbitration provisions of the convention. By ratifying the convention, or (in the case of individuals) signing a contract containing the same provisions, the parties would be deeined to have submitted to the jurisdiction of the arbitration tribunal. Disputes over jurisdiction and the tribunal's power to render a decision would thus be minimized.

Third, submission of the dispute to arbitration is less hikely to engender conflict over questions of sovereignty. By ratifying the convention or signing a contract, the parties would have agreed in advance to abide by the arbitrators' decision. The parties could make no pohicy argument against such an agreement, because they theinselves would have vested the tribunal with binding authority. In contrast, if the court of one state were to choose the governing substantive law and to apply it, a party could argne that the court had no power to render such a decision and that on pohicy grounds the judgment should not be enforced. ${ }^{191}$

Fourth, arbitration of the plaintiff's elaim maximizes the chanees for an impartial decision. Allowing the plaintiff to bring suit in her state's court system presents the danger that the court would be improperly influenced by the plaintiff's nationality, especially if the defendant is not a national of that state. Moreover, since each party would appoint one arbitrator to the three-person panel, ${ }^{192}$ even the appearance of undue

doors are closed on Earth following embarkation until the moment when one such door is opened on Earth for disembarkation.

189. Comment, supra note 10 , at 1939.

190. Id. at $1942-43$.

191. The Convention on the Recognition and Enforcement of Foreign Arbitral Awards allows a state party to the Convention to refuse enforcement of an arbitral award only in certain enumerated circumstances; one such exception is when enforcement "would be contrary to the public policy of" the state being asked to enforce the award. June 10, 1958, art. V, § (2)(b), 21 U.S.T. 2517, 2520, 330 U.N.T.S. 3, 42.

192. Under the UNCITRAL Model Law, the parties are free to set the number of arbitrators at more or less than three, and to determine the procedure for seleeting the arbitrators. In the absence of such an agreement, each party appoints one arbitrator and the two arbitrators then select a third. If the two arbitrators cannot agree, a court may appoint the third arbitrator. UNCITRAL Model Law, supra note 16, arts. 10, 11. 
influence by one party or state could be avoided.

Fifth, an arbitration tribunal is much less likely than a state court to fail to apply one of the three enumerated sets of laws. Although the court would follow the choice of law approach mandated by the proposed convention, there could be policy concerns hindering a state court's application of the convention even if the parties did not wish to deviate. The court could justify such deviations because it derives its authority ultimately from the state. The arbitral tribunal, on the other hand, would derive its authority solely from the parties and its decision could be challenged if it failed to follow their directions.

\section{CONCLUSION}

A space station planned, constructed, and staffed by several states probably will be im operation before the end of the century. The legal issues which will arise are hikely to involve parties from different states. Thus, any body adjudicating these issues must determine which state's laws govern those issues.

The most equitable solution for tort cases would be an adaptation of American choice of law practice in maritime law. The tribunal hearing the plaintiff's claims would consider the state of registry of the MSS, the plaintiff's state, and the defendant's state, and would then apply the substantive law of one of these states. Although other approaches have been proposed, either they are based on choice of law methodologies that are not widely accepted or they have problems in their application. The method suggested herein, in contrast, should be acceptable to most states since it is based on maritime law, which is (in theory) the same everywhere. Using the technique proposed in this Comment, the tribunal is strictly limited in its exercise of discretion but has sufficient discretion with which to avoid injustice.

The tribunal should be an arbitration panel governed by the UNCITRAL Model Law. Flexibility and impartiality, characteristics not common to litigation, militate strongly in favor of arbitration. Moreover, international arbitration would be less likely to impinge on a state's autonomy than would litigation im another state's courts. Finally, arbitration will ensure that the plaintiff's claim is resolved through the choice of law technique suggested by this proposed convention. 